\title{
WIRES
}

WATER

WILEY

\section{Physical and biological controls on fine sediment transport and storage in rivers}

\begin{tabular}{|r|l|}
\hline Journal: & WIREs Water \\
\hline Manuscript ID & WATER-450.R1 \\
\hline Wiley - Manuscript type: & Advanced Review \\
\hline Author: & n/a \\
\hline Complete List of Authors: & $\begin{array}{l}\text { Wilkes, Martin; Coventry University, Centre for Agroecology Water and } \\
\text { Resilience } \\
\text { Gittins, Joshua; Lancaster Environment Centre } \\
\text { Mathers, Kate; Eawag - Swiss Federal Institute of Aquatic Science and } \\
\text { Technology } \\
\text { Mason, Richard; Loughborough University Department of Geography } \\
\text { Casas-Mulet, Roser; Technical University of Munich, Department of } \\
\text { Ecology and Ecosystem Management; Cardiff University; University of } \\
\text { Melbourne Department of Infrastructure Engineering } \\
\text { Vanzo, Davide; Eawag - Swiss Federal Institute of Aquatic Science and } \\
\text { Technology } \\
\text { Mckenzie, Morwenna; Coventry University, Centre for Agroecology Water } \\
\text { and Resilience } \\
\text { Murray-Bligh, John; Environment Agency } \\
\text { England, Judy; Environment Agency } \\
\text { Gurnell, Angela; Queen Mary, University of London, Geography } \\
\text { Jones, J. Iwan; Queen Mary University of London - Mile End Campus }\end{array}$ \\
\hline Choose 1-3 topics to & \\
\hline categorize your article: & \\
\hline Keywords: & \begin{tabular}{l} 
River, Fine sediment, Ecosystem engineering, Geomorphology, Ecology \\
\hline
\end{tabular} \\
\hline
\end{tabular}




\section{Article Title: Physical and biological controls on fine sediment transport and storage in rivers}

\section{Article Type:}

ADVANCED REVIEW

\section{Authors:}

[List each person's full name, ORCID iD, affiliation, email address, and any conflicts of interest. Copy rows as necessary for additional authors. Please use an asterisk $\left(^{*}\right)$ to indicate the corresponding author.]

\begin{tabular}{|l|}
\hline Martin A. Wilkes* \\
orcid.org/0000-0002-2377-3124 \\
martin.wilkes@coventry.ac.uk \\
Centre for Agroecology, Water and Resilience, Coventry University, United Kingdom \\
\hline Joshua Gittins \\
orcid.org/ 0000-0002-6098-8917 \\
j.gittins1@lancaster.ac.uk \\
Lancaster Environment Centre, Lancaster University, United Kingdom \\
\hline Kate L. Mathers \\
orcid.org/0000-0003-3741-1439 \\
kate.mathers@eawag.ch \\
Eawag - Swiss Federal Institute of Aquatic Science and Technology, Kastanienbaum, \\
Switzerland \\
\hline Richard Mason \\
R.J.Mason@lboro.ac.uk \\
Department of Geography, Loughborough University, United Kingdom \\
\hline
\end{tabular}




\begin{tabular}{l} 
Roser Casas-Mulet \\
orcid.org/0000-0002-7139-8859 \\
roser.casas-mulet@tum.de \\
Aquatic Systems Biology Unit, Department of Ecology and Ecosystem Management, \\
Technical University of Munich, Bavaria, Germany; Water Research Institute, Cardiff \\
University, Wales, UK; Department of Infrastructure Engineering, The University of \\
Melbourne, Victoria, Australia \\
\hline Davide Vanzo \\
orcid.org/0000-0002-2033-9197 \\
davide.vanzo@eawag.ch \\
Eawag - Swiss Federal Institute of Aquatic Science and Technology, Kastanienbaum, \\
Switzerland \\
\hline Morwenna Mckenzie \\
orcid.org/0000-0001-8906-4286 \\
mckenz36@uni.coventry.ac.uk \\
Centre for Agroecology, Water and Resilience, Coventry University, United Kingdom \\
\hline John Murray-Bligh \\
john.murray-bligh@environment-agency.gov.uk \\
Environment Agency, Exeter, United Kingdom \\
\hline Judy England \\
orcid.org/0000-0001-5247-4812 \\
judy.england@environment-agency.gov.uk \\
Environment Agency, Exeter, United Kingdom \\
\hline Angela Gurnell \\
orcid.org/0000-0002-7249-8202 \\
a.m.gurnell@qmul.ac.uk \\
School of Geography, Queen Mary University of London, United Kingdom \\
\hline J. Iwan Jones \\
orcid.org/0000-0002-7238-2509 \\
j.i.jones@qmul.ac.uk \\
School of Biological and Chemical Sciences, Queen Mary University of London, United \\
Kingdom
\end{tabular}

\begin{abstract}
Excess fine sediment, comprising particles $<2 \mathrm{~mm}$ in diameter, is a major cause of ecological degradation in rivers. The erosion of fine sediment from terrestrial or aquatic sources, its delivery to the river, and its storage and transport in the fluvial environment are controlled by a complex interplay of physical, biological and anthropogenic factors. Whilst the physical controls exerted on fine sediment dynamics are relatively well-documented, the role of biological processes and their interactions with hydraulic and physico-chemical phenomena has been largely overlooked. The activities of biota, from primary producers to predators, exert strong controls on fine sediment deposition, infiltration and resuspension. For example, extracellular polymeric substances (EPS) associated with biofilms increase deposition and decrease resuspension. In lower energy rivers, aquatic macrophyte growth and senescence is are intimately linked to sediment retention and loss, whereas riparian trees are dominant ecosystem
\end{abstract}


engineers in high energy systems. Fish and invertebrates also have profound effects on fine sediment dynamics through activities that drive both particle deposition and erosion depending on species composition and abiotic conditions. The functional traits of species present will determine not only these biotic effects but also the responses of river ecosystems to excess fine sediment. We discuss which traits are involved and put them into context with spatial processes that occur throughout the river network. Whilst strides towards better understanding of the impacts of excess fine sediment have been made, further progress to identify the most effective management approaches is urgently required through close communication between authorities and scientists.

\section{Graphical/Visual Abstract and Caption}

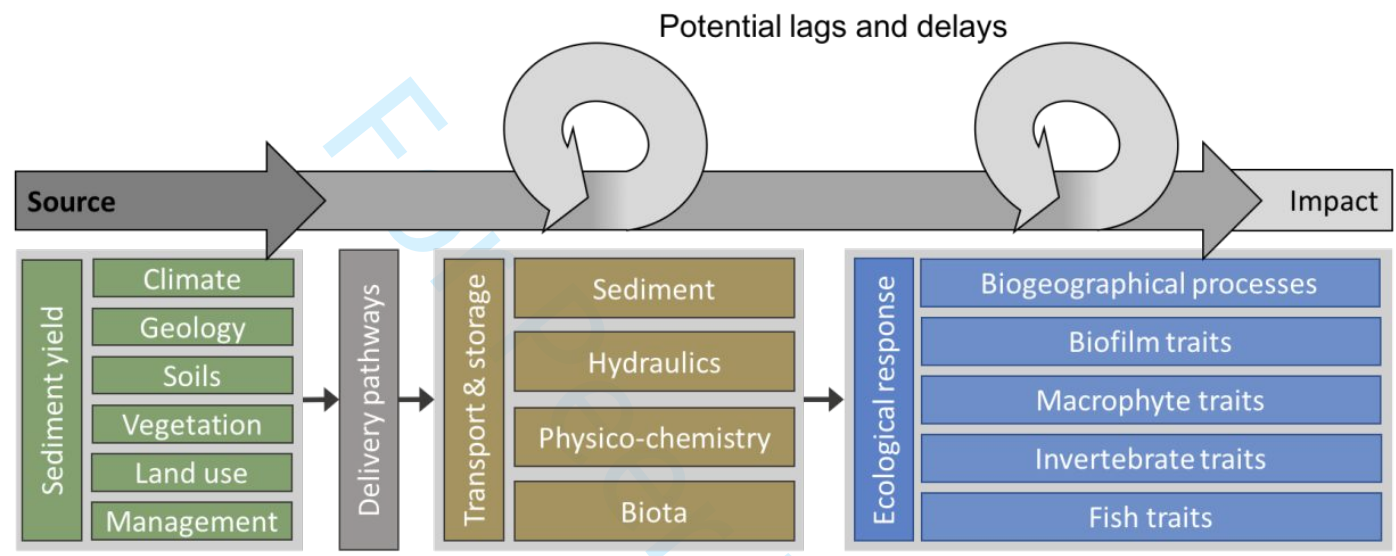

Controls on the delivery, transport and storage of fine sediment and the resulting ecological responses in river networks. From the sediment sources in the landscape to the ecological impact in the river, the transport of particles and the responses of biota are subject to potential lags and delays as sediment is temporarily stored and time is taken for local populations to reach critical life-stages where fine sediment limits survival.

\section{Introduction}

Excess fine sediment ('fines'), typically defined as organic and inorganic particles $<2 \mathrm{~mm}$ in diameter, is one of the principal reasons for the failure of waterbodies to achieve good ecological status (GES) under the EU Water Framework Directive (WFD) ${ }^{1,2}$. In light of this, the recent finding that most lowland rivers in the UK are transport-limited, leading to saturation of river bedsstreambeds with fine sediment ${ }^{3}$, is of critical importance. We may safely assume that this result can be generalised to other similar environments worldwide. It implies that in-channel transport and storage processes are primary controls on the volume of fines stored on or within the river bedstreambed, whereas both exogenous (i.e. sediment supply) and endogenous processes (e.g. bioturbation) primarily influence the concentration of fine sediments carried in suspension and their flux through the river network. Greater understanding of these processes is urgently required. To facilitate progress in the primary research areas involved, we provide a synthesis of current knowledge on the physical and biological factors controlling the transport, storage and ecological impacts of fine sediment in river channels to complement recent reviews on catchment-scale, terrestrial processes (e.g. ${ }^{4}$ ). 
In reviewing the factors that control fine sediment transport and storage in river channels, we emphasise biological controls as these have received far less attention than physical controls (e.g. ${ }^{5}$ ). Bottom-up, biologically-driven forces are increasingly recognised as important elements for understanding fluvial geomorphic processes ${ }^{6}$. We build upon this knowledge in the specific context of fines. Ecological impacts at organism- and community- levels, driven by top-down abiotic forces, have been reviewed in detail elsewhere ${ }^{7-10}$ but how the ecological response to fine sediment is mediated by the structure and function of ecosystems across multiple levels of organisation is less well-understood. We therefore also include information on ecological resistance (ability to withstand perturbation) and resilience (ability to recover from disturbance) to fine sediment stress at the level of individual organisms to regional biogeographies. We mostly limit the discussion to processes occurring after the sediment has been delivered to the river channel but also present some exogenous processes insofar as they influence in-channel controls. Our discussion is structured according to the conceptual model in Figure 1, going beyond a recent review on infiltration ('colmation') ${ }^{11}$ to provide a more holistic perspective on the fine sediment 'problem'.

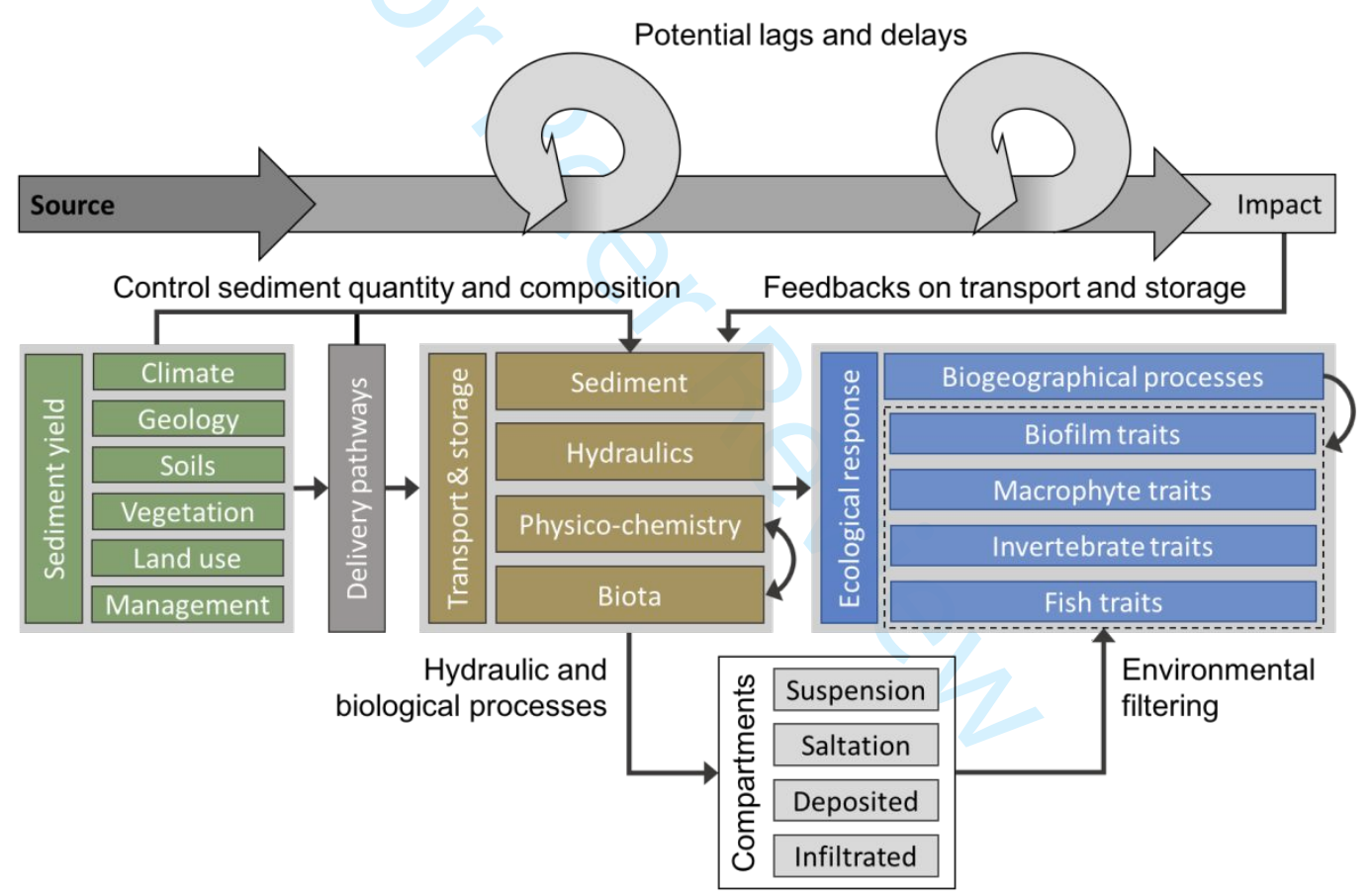

Figure 1 - Controls on the delivery, transport and storage of fine sediment and the resulting ecological responses in river networks. Natural and anthropogenic factors control the quantity and quality of sediment potentially available for delivery to the river channel. Whether or not this potential is realised, and the quantity and composition of sediment conserved during the pluvial phase, depends on delivery pathways that connect the source to the river channel. Once delivered to the river channel, particles may be transported through suspension or saltation, temporarily stored as surface-deposited material, or become infiltrated in the river bedstreambed and stored on a longer-term basis. Which compartment particles are transported or stored in depends on a number of controls, including the inherent properties of the particles, hydraulics, and the activities of biota. The latter is in turn influenced by 
physico-chemical factors (e.g. oxygen, nutrients) that work to limit or enhance biological processes. The hydraulic and biological controls determine the compartments within which particles are transported or stored, structuring the physical habitat, modifying available resources and potentially filtering out unsuitable species from the species pool on the basis of their traits. Such environmental filtering effects may be interfered with by biogeographical processes related to dispersal. The fate of fine sediment, and

the extent and nature of the impact it causes is subject to potential lags as sediment is temporarily

stored within the landscape. Ecological impacts may also be delayed as time is taken for local populations to reach critical life-stages where fine sediment limits survival.

\section{CONTROLS ON SEDIMENT YIELD AND DELIVERY TO THE RIVER CHANNEL}

The yield of fine sediment to the river channel from the catchment (expressed as specific yield, $t \mathrm{~km}^{-2} \mathrm{yr}$ ${ }^{1}$ ) is a consequence of the mobilisation of sediment from a variety of sources, the transport of that sediment through the landscape and any storage, either temporary or longer-term, within the landscape. Hence, many factors influence the quantity and composition (including inter alia grain size, organic content, and associated contaminants and nutrients) of fine sediment delivered to the channel. Whilst soil type, climate and geology have a major influence on the mobilisation of fine sediment, their effects are modified by local factors, including topography, land-use, vegetation and management. As the mobilised fine sediment is transported through the landscape from the source to the river, there is further potential for sorting and retention to influence the quantity and composition of the sediment ultimately delivered to the river channel. For this reason, well-connected sources tend to contribute most to the fine sediment yield.

As the characteristics of sediment from different locations and sources vary (e.g. arable land, road verges), methods have been developed to identify and apportion the contributions from the various potential sources of both the inorganic (e.g. ${ }^{12,13}$ ) and organic (e.g. ${ }^{14}$ ) components of fine sediment sampled from rivers. Such source apportionment studies indicate that some sources contribute disproportionately relative to their area in the catchment, particularly those that are well-connected, either arising close to the river or involving pathways over impervious surfaces, or both (e.g. direct inputs from sewage treatment works, damaged road verges ${ }^{14-16}$. Part of the yield is derived from natural processes such as unenhanced background erosion of soils and river banks. However, the dominance of human influences on the landscape has affected fine sediment dynamics since early agriculture ${ }^{17-19}$. More recently, the total yield of fine sediment has increased from historical levels, particularly in the post-war years with the intensification of agriculture and expansion of urban areas ${ }^{20}$, such that agricultural, industrial and urban sources now contribute a substantial proportion, if not the majority of the yield of fine sediment to rivers $^{2}$. As such, both the quantity and composition of fine (inorganic and organic) sediment delivered to rivers far exceeds modern background levels; the estimated total loss of sediment in England and Wales was 1,389,818 t yr-1 in excess of target modern $\underline{\text { background delivery rates }}{ }^{21}$, defined as the early twentieth century up to $\sim 1940^{20}$. (defined as the early twentieth century up to $\sim 1940)^{20,21}$ - 


\section{ABIOTIC CONTROLS ON FINE SEDIMENT TRANSPORT AND STORAGE}

\section{Controls on fine sediment: Hydraulics and geomorphology}

Transport and storage of fines in streambeds plays a key role in the natural development of the sediment matrix ${ }^{22-24}$, contributing to habitat quality and quantity by influencing the hydrological and geomorphological behaviour of a river ${ }^{25}$. Fine sediments are composed of organic and inorganic components that are transported in rivers as solid load or may precipitate from the dissolved load $(<0.45 \mu \mathrm{m})$. The majority of fines move through river systems as solid suspended load $^{26}$ in the form of flocculated or aggregated particles due to their cohesive nature ${ }^{27}$. The load of fine sediments in a river will be determined by the relationship between flow conditions and the structure, density and size of the sediment particles.

The magnitude and timing of events exhibiting high suspended sediment loads is-are closely related to the hydrological regime. In rivers with a near-natural flow regime, sediment transport is positively correlated with flow intensity ${ }^{28}$. Human alterations, such as dams and channelisation, that modify or disrupt the flow and sediment longitudinal continuity ${ }_{L}$ have multiple effects on sediment dynamics and the morphology of downstream reaches ${ }^{29}$. Moreover, sediment flushing operations adopted for the maintenance of reservoirs can lead to extreme events characterised by high suspended sediment loads and the potential for widespread deposition downstream ${ }^{30}$.

Most accumulation of fines in the streambed occurs as a result of gravitational deposition from the suspended load ${ }^{5,22,23,31-33}$. Hydraulic conditions in the water column determine whether such deposited fines are stored on the bed surface, resuspended ${ }^{34}$, or infiltrated into the bed ${ }^{11}$. Pressure gradients at the bed sediment-water interface ${ }^{35,36}$ may promote suspended sediment advection into the porous matrix via downwelling and upwelling mechanisms ${ }^{23,33,37,38}$. Such pressure gradients are induced by bedforms ${ }^{35,39}$, local heterogeneity or roughness and permeability changes in the streambed ${ }^{40}$, including those created by biotic activity. Fines infiltrating into the streambed may settle within the pore spaces of the sediment matrix ${ }^{41}$, or be transported laterally and longitudinally through the streambed ${ }^{42}$. In the upper bed layers, such horizontal transport ('Brinkman load' in Figure 2) may result from turbulent mixing promoted by shear instability above the bed ${ }^{5,43,44}$. In the lower layers, subsurface (Darcian) flow driven by hydraulic gradients ${ }^{45}$ may transport fines through the interstitial spaces of the sediment matrix $^{44}$ ('interstitial load' in Figure 2). 


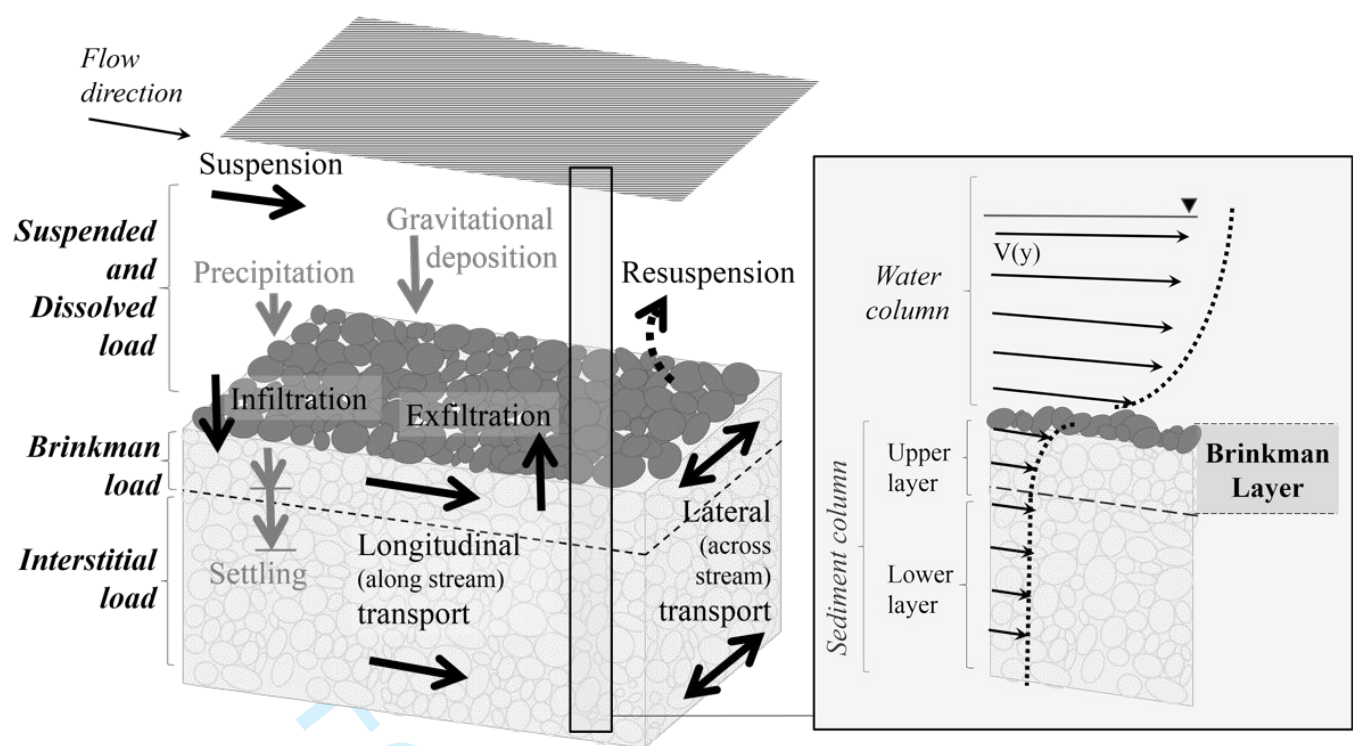

Figure 2 - Fine sediment transport (black arrows) and deposition (grey arrows) processes in gravel beds. These processes occur in three key load regions (suspended and dissolved load, Brinkman load and interstitial load) within the water and sediment columns in which such processes occur (left). The model proposes distinct modes of sediment transport in these three regions identified by transitions in the velocity profile $\mathrm{V}(\mathrm{y})$ (right). Modified from ${ }^{44}$.

\section{Controls on fine sediment: Physico-chemsistry}

The physico-chemical properties of fines are typically considered to be secondary in importance to their physical characteristics in terms of generating ecological impacts, yet there are clear feedbacks between the sediment, its chemical constituents and those of the water-column, and biotic activity. Indeed, the chemical composition of fine sediment may be more influential on invertebrate assemblage structure ${ }^{3,46,47}$ and the survival of fish eggs ${ }^{48,49}$ than the volume of fines deposited on the benthos ${ }^{50}$. However, it is generally acknowledged that combined multiple stressor effects are complex and poorly understood ${ }^{51,52}$. Some of the better understood feedbacks between the physico-chemical properties of fines and their dynamics are related to biological processes. For example, the scattering and prevention of solar radiation by turbid conditions caused by excess suspended sediment is known to be detrimental to benthic ecology by reducing rates of photosynthesis ${ }^{53,54}$. Similarly, high suspended sediment concentrations (SSC) drive temperature gradients with depth in the water column ${ }^{55}$, with consequences for biotic activity. Another well-studied impact on the benthic community is a reduction in hyporheic exchange flow due to the deposition of excess fine sediment ${ }^{11,56}$. Within the interstices, the breakdown of fine particulate organic matter (FPOM) increases sediment oxygen demand, exacerbating the hypoxia initiated by physical clogging ${ }^{49,57-60}$. Under such conditions, methanogenic microbial communities develop at the oxic-anoxic interface, resulting in the precipitation of ocherous masses of iron hydroxides ${ }^{61}$ and further saturating the bed matrix with fine particulate matter.

Many of the direct physico-chemical impacts of fines on stream biota are ecotoxicological in nature, driving feedbacks by increasing or decreasing the biological controls exerted on fine sediment dynamics 
(Figure 1). Nutrients, heavy metals and organic pollutants can adsorb to and desorb from fine particles due to their high affinity as carriers ${ }^{25,62,63}$. Their sorption potential depends upon the properties of the sediment, i.e. grain size, mineralogical composition, organic matter content and cation exchange capacity ${ }^{64}$. The physico-chemical weathering of sediments during their 'life-cycle' is driven by water column concentrations of major ions and trace chemical constituents ${ }^{65}$, in addition to biological and hydrodynamic processing and sorting. However, additional physico-chemical factors, such as dissolved oxygen, $\mathrm{pH}$ and temperature have also been implicated in controlling the sorption dynamics of potentially harmful substances, including heavy metals ${ }^{66}$ and nutrients ${ }^{67}$.

The desorption of these substances may increase bioavailability, allowing contaminants to enter the food web along with those contaminants adsorbed to fines that are ingested by biota. For example, the exchange of various phosphorus $(P)$ forms between the particulate (bound) and dissolved (free) pools within freshwaters is now well-documented to be influenced by $\mathrm{pH}$, temperature and dissolved oxygen ${ }^{68}$. These interactions can either promote or inhibit growth depending on the stoichiometric abundance of nutrients or the toxicity of contaminants ${ }^{69-71}$. Other physico-chemical factors affecting fines may disrupt their transport and deposition mechanics. An increase in the deposition of fines due to flocculation and precipitation has been seen due to modification of $\mathrm{pH}$ and ionic salt concentrations in freshwaters ${ }^{72-74}$. The most widely known examples are changes in redox potential leading to the deposition of calcium salts (tufa) and ocherous masses. Temperature regulated streamwater viscosity is also known to increase particulate deposition ${ }^{75}$. These physico-chemical feedbacks between fines, the water-column and biotic activity have complex, cascading effects on geomorphic processes.

\section{BIOLOGICALBIOTIC CONTROLS ON FINE SEDIMENT TRANSPORT AND STORAGE}

The two-way interactions between biota and the environment have long been of interest to both physical and biological scientists. However, it was not until recent decades that they were more intensively investigated under a multitude of frameworks, including zoogeomorphology, ecogeomorphology, biogeomorphology and ecosystem engineering ${ }^{76-78}$. Below we briefly review the body of research that has emerged from application of these frameworks to biofilms, aquatic macrophytes and riparian vegetation, invertebrates and fish. In doing so, we highlight the key effect traits $^{79}$ that determine the potential of biota to influence fine sediment dynamics (Table 1).

\section{Controls on fine sediment: Biofilms}

Biofilms, referred to as 'cities of microbes' ${ }^{80,81}$ comprising bacteria, fungi and algae ${ }^{82}$, are known to affect and be affected by fine sediment dynamics ${ }^{83-86}$. Although the important function biofilms fulfil in wastewater processing has long been known, it was not until more recently that research began to focus on their role in the processing and fate of fine sediment-bound contaminants in freshwater ecosystems ${ }^{87-}$ 91. The matrix of the biofilm microenvironment is comprised mostly of extracellular polymeric substances (EPS)EPS ${ }^{92,93}$, which are synthesised by the biofilm microbial community. The properties of these EPS are influential on the sediments upon which they establish, altering their physico-chemical characteristics and, therefore, their dynamics through bioflocculation ${ }^{94}$. An experimental study ${ }^{95}$ found that the erodibility and resulting resuspension of settled cohesive sediments was reduced with weak biofilm EPS 
growth when exposed to low shear stress (<0.1 Pa). Longer periods (up to 12 days) of undisturbed growth under low shear stresses $(<0.1 \mathrm{~Pa})$ allowed the establishment of a biofilm-EPS structure that could reduce erosion under increased shear stresses of up to $0.4 \mathrm{~Pa}$. These results, along with other studies in agreement ${ }^{85,96,97}$, demonstrate that biofilm growth and the corresponding EPS synthesis allows for increased cohesion between fine sediment grains (Figure 3). This potentially increases the deposition of fines and reduces their resuspension ${ }^{98}$.

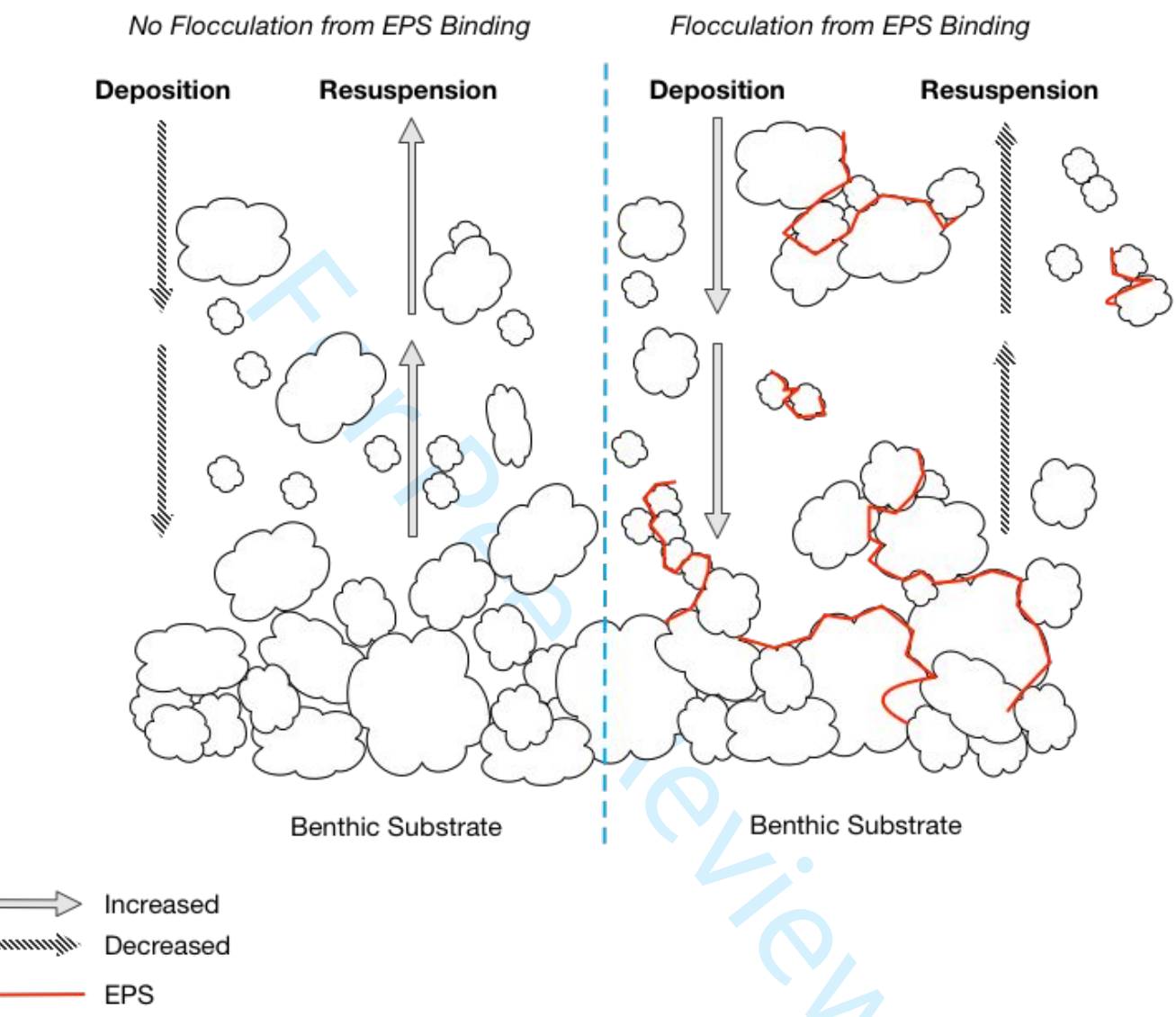

Figure 3 - Controls on fine sediment deposition and resuspension exerted through bioflocculation by extracellular polymeric substances (EPS) in biofilms.

Fine sediments also interact with sediment-water exchanges of nutrients associated with biofilm communities ${ }^{27}$, typically increasing community growth and EPS synthesis. During a flume study ${ }^{87}$, concentrations of soluble reactive phosphorus (SRP) were reduced through the trapping of fine particulates in biofilms. Bed sediments with larger surface areas for biofilm and filamentous algal growth resulted in a greater flux of SRP than fine sediments alone, which are unable to support filamentous growth. Furthermore, evidence that nutrient stoichiometry is influenced by fine sediment dynamics has been linked to changes in biofilm growth and species composition ${ }^{99,100}$; although it is acknowledged that physico-chemical factors also play a role ${ }^{101-103}$. The growth of biofilms has also been found to influence fine sediment transport and bed morphology ${ }^{85,104}$. Modelling following experimental observations has 
demonstrated that biofilm-coated fines have a greater saltation length-height ratio, suggesting that particle deposition and settling is more likely than in uncoated fines, depending on water velocity ${ }^{105}$. More recently, a microbiological-physical model (BFLOC2) of suspended sediment aggregation and settling velocity was established ${ }^{106}$. The model shows that microbial biomass, cell motility and aggregate-attached food web interactions are significant controls on fine sediment dynamics. In summary, the interactions between biofilms and fine sediments are driven by a balance between physico-chemical and biotic influences on the processing, transport and fate of particles.

\section{Controls on fine sediment: Macrophytes and riparian vegetation}

Awareness of the intimate links been vegetation and river landforms and processes emerged during the last century ${ }^{107-109}$. However, recognition of the complex interactions between riparian vegetation and fluvial processes that result in sediment retention and landform building has only emerged strongly in the last two decades ${ }^{110-112}$. It is now recognised that particular plant types, materials and species are key to these interactions, driving meso- to macro- scale sediment retention and building landforms. Examples of the broad types of plants and plant-derived material include emergent ${ }^{113,114}$ and submerged $^{115}$ aquatic macrophytes; dead ${ }^{116}$ and living deposited trees ${ }^{117,118}$, tree fragments ${ }^{119}$ and accumulations of fragments ${ }^{120}$.

Interactions between plants and any fine sediment transported by rivers are particularly important because small sediment particles are easily mobilised, even at low flow velocities, and so their storage relies on them being retained in sheltered locations. The above-ground biomass of plants offers such shelter to exert control on fine sediment retention. The extent to which plants drive such retention is dependent on their ability to affect local hydraulic conditions, and hence their morphology and the stiffness and density of their stems ${ }^{9}$. The greater the resistance the plant presents to flow, the greater the retention of sediment ${ }^{121,122}$. Once a critical flow resistance (frontal area drag coefficient) has been achieved, plants will tend to retain sediment ${ }^{123}$. Aquatic plants have the ability to grow through the retained sediment, reinforcing it with their stems, roots, rhizomes and other below-ground organs and driving the further accumulation of fine sediment into erosion-resistant, aggrading landforms such as bars, benches, river banks, islands and floodplains ${ }^{124}$. In lower energy river systems, aquatic macrophytes may be more important as ecosystem engineers than riparian plants ${ }^{9,121,125}$. For example, the emergent macrophyte Sparganium erectum is a very effective river ecosystem engineer in British lowland rivers ${ }^{126}$. A beneficial effect of sediment retention by plants can be that, as the fine sediment landforms emerge from the river bedstreambed, they narrow the width of river channel available for water, leading to increased flow velocities in the area occupied by water and thus increased transport and (re)mobilisation of fine sediment from any coarser bed material. The result is a more heterogeneous river bedstreambed supporting patches of contrasting particle size. Conversely, extreme macrophyte growth in dense stands may reduce flow velocities throughout the river channel, causing more sediment retention and homogenisation of the physical habitat ${ }^{127}$. This process could eventually lead to infilling of the channel. Indeed, it could be argued that such circumstances often arise as a response to the artificial creation or enlargement of stream channels, flow regulation and/or excessive inputs of fine sediment. Whatever the cause, available stream power is insufficient to control macrophyte growth and flush fine sediments $^{114,128}$. Regardless of the causeln any case, the fine sediments retained by macrophytes 

processes and river morphology may have a notable role in organic matter retention. Such effects are likely to be more pronounced in nutrient-enriched waters.

As river energy increases, macrophytes are unable to resist the increasing shear stresses imposed by river flows, and their engineering role is taken up by riparian plants, particularly trees. All tree species growing along river margins interact with fluvial forms and processes through a 'large wood cycle'. Tree or branch fall introduces large pieces of wood into rivers, where they can snag and accumulate into wood jams or dams, providing retention structures for other organic material, sediments and seeds ${ }^{116}$. In unmanaged situations, these processes drive a cycle of sediment and seed retention, germination and growth, and incorporation of the aggrading vegetated landforms into islands and floodplains where they support the growth of trees and thus the delivery of more large wood to the river ${ }^{130}$. Across the temperate zone of the Northern Hemisphere, the Salicaceae (willows and poplars) are particularly important river ecosystem engineers ${ }^{131}$. Riparian species of willow and poplar not only drive a 'dead' wood cycle, as described above, but the ability of wood from these species to sprout and grow remarkably rapidly, makes them particularly effective river ecosystem engineers. Furthermore, these species can produce roots from buried stems and shoots from roots allowing them to strongly reinforce sediments to depths of several metres ${ }^{132-134}$.

Recent reviews ${ }^{124,135}$ conceptualise the crucial interactions between plants and fluvial processes that influence sediment retention and reinforcement, the building of landforms such as scroll bars ${ }^{136}$, islands, river banks and floodplains that are the result of these interactions, and the ways in which these processes and forms vary through time and across space. During the storage period in these landforms, the properties of fine sediments may change under the influence of biogeochemical processes and the activities other biota that colonise the new landforms. This could include invasive species, such as the tall growing annual Himalayan balsam (Impatiens glandulifera) which may increase the risk of bank erosion during the winter period ${ }^{137,138}$. The controls on fine sediment transport and storage exerted by plants, therefore, may be shifting as invasive species become established.

\section{Controls on fine sediment: Invertebrates}

Lotic invertebrates are key ecosystem engineers, being ubiquitous in rivers and often present at considerable densities. For this reason, despite their typically small body sizes (e.g. $<50 \mathrm{~mm}$ ), invertebrates can have substantial cumulative impacts on the storage and transport of fines ${ }^{139}$. Crustaceans are perhaps the most widely studied geomorphic agents in rivers and can influence all aspects of fine sediment dynamics ${ }^{140}$. Crayfish can destabilise river bedsstreambeds during activities such as foraging and fighting, and a number of studies have documented an increase in turbidity attributed to bioturbation by crayfish ${ }^{140,141}$. High densities of invasive The presence of crayfish can result in a 50-75\% reduction in the shear stress required to entrain sand, leading to increases in sediment fluxes of as much as $32 \%{ }^{142}$. Invasive signal crayfish (Pacifastacus leniusculus) can also enhance the delivery of fine sediment to rivers through increasing bank erosion with high densities of burrows (up to 14 burrows $\left.\mathrm{m}^{-1}\right)^{142,143}$. 
Aquatic insects can increase the suspension of fine sediment by winnowing it from interstitial spaces during foraging activity ${ }^{144,145}$. The stonefly (Dinocras cephalotest has the potential to erode $200-400 \mathrm{~kg}$ $\mathrm{m}^{-2} \mathrm{yr}^{-1}$ of sand, with reduced prey availability increasing rates of sand erosion ${ }^{146}$. The mayfly species Pseudiron centralis manipulates near-bed hydraulics to disturb sand and facilitate capture of its prey ${ }^{147}$. This latter example demonstrates that some invertebrates are actively seeking to control sediment dynamics, an instance of extended phenotype engineering, whereby organisms create structures that directly influence their fitness and survival ${ }^{78}$. Invertebrate bioturbation has also been documented to influence sediment structure. Upward conveyors (Oligochaeta) and gallery-diffusers (Chironomidae) can reduce the clogging of bed sedimentsstreambeds, helping to restore hyporheic exchange flow and physiochemical conditions at the surface-subsurface interface ${ }^{148-153}$. Molluscs have been reported to both disturb sediment during movement and consolidate it whilst stationary ${ }^{154}$. Flow resistance generated by the shells of bivalve molluscs can also promote localised scour ${ }^{155}$. Different modes of bioturbation (sediment reworking, biogenic structure building, burrowing depth, bioirrigation) can also determine the impact of benthic invertebrates on microbial activities and biogeochemical processes in the sediment ${ }^{156}$.

Hydropsychidae is one of the most abundant families of lotic insects worldwide, often accounting for as much as $80 \%$ of invertebrate biomass in some streams and, consequently, exerting substantial controls on geomorphic processes ${ }^{157-159}$. Hydropsychids construct nets to filter FPOM from the water column, increasing the force required to entrain bed sediments by $10-30 \%{ }^{142,160}$. This effect increases with the density of individuals and the local richness of species exhibiting similar behaviours ${ }^{161}$. Through netspinning, hydropsychid caddisflies increase the force required to erode armour layers and therefore reduce exposure of underlying fine sediments to entraining flows ${ }^{162}$. Many other species of caddisfly are also known for their construction of cases from mineral and organic sediment. These cases utilise a wide range of particle sizes and may be responsible for the storage of significant quantities of temporary storage of fine sediment ${ }^{163,164}$. Blackflies (Simuliidae), bivalve molluscs and other filter feeding invertebrates are also involved in driving storage of fine sediment by consolidating suspended particles from the water into faeces or pseudofaeces, thus increasing the rate of sedimentation and altering the composition of suspended solids ${ }^{165,166}$.

The sheer diversity of aquatic invertebrate species ( $85 \%$ of global freshwater animal diversity ${ }^{167}$ ), and the densities in which they are often present, complicate understanding of their role in the transport of fines. In particular, interactions between coexisting species probably play an important role in mediating the impacts of excess fine sediment, yet these interactions are rarely considered ${ }^{161}$. It should also be noted that the effect of biota on fine sediment dynamics will vary spatially and temporally. Four main factors have been suggested as primary controls on the impact that animals have on the environment; behaviour, body size, density and abiotic context ${ }^{165,166}$.Despite management advances made in recent decades, especially in relation to organic pollution, freshwater biota face increasing challenges for survival, including habitat degradation, species invasions, pollution, climate change, and increasing urbanisation ${ }^{168,169}$. Invertebrates are one of the most affected taxonomic groups ${ }^{170,171}$ and this could have consequences, not just for biodiversity, but also fine sediment dynamics in the future.

Controls on fine sediment: Fish 
Fish can exert controls on fine sediment dynamics through a number of activities. Relative to other taxonomic groups, the controls exerted by fish are well-documented, most notably feeding and spawning ${ }^{140}$-. We therefore provide only a brief summary here. To date, salmonid spawning has attracted the most attention. During spawning, female salmon create redds (nests) by disturbing the bed with strong undulations of their tails ${ }^{172}$. This activity leads to the suspension of fines and modifies bed stability by vertically mixing gravels and fine sediments and disturbing existing armour layers ${ }^{173-175}$. Tail slips (material excavated from redds) are particularly vulnerable to scour ${ }^{175,176}$. Spawning salmon substantially modify topography across large areas of the bed ${ }^{177}$. This effect persists until the next high flow event of sufficient magnitude ${ }^{178}$, exerting a strong, temporary control on the hydraulic processes driving fine sediment dynamics.

Put into perspective, the spawning activities of salmon and other lithophilous fish can have considerable geomorphic impacts at large spatial scales. The vertical mixing of material by salmon may be at a comparable magnitude to that driven by floods, resulting in lower critical shear stresses required to initiate bed movement ${ }^{179}$. In some cases, salmon can be responsible for a substantial proportion of annual sediment transport. A study in British Columbia studyestimated that salmon account for one third to one half of total annual sediment flux in gravel bed streams ${ }^{178}$. So strong is this effect that the evolution evolution of freshwater fish mayof multiple Pacific salmon species from a common ancestor may have consequences for landscape evolution over geological timescalesprofoundly influence channel erosion processes and stream profiles over geological timescales, as suggested by a coupled biologicallandscape evolution model focusing on the descent of Pacific salmon species from a common ancestor $^{180}$.

Benthivorous fish also have significant impacts on fine sediment suspension while foraging. Cyprinid species can substantially alter sediment dynamics, increasing mixing depth and suspended sedimentSSC ${ }^{181,182}$. Foraging barbel, for example, can increase total sediment yields by as much as $82 \%{ }^{183}$. The geomorphic impacts of benthivorous foraging increase with fish density ${ }^{184-187}$, with the body size and mass of individuals ${ }^{188}$, and with the presence of specific feeding behaviours. European barbel (Barbus barbus), for example, feed in both gravel and sand sized substrates, while gudgeon (Gobio gobio) feed largely in sand habitats and, therefore, their geomorphic impacts are spatially limited ${ }^{189}$. Fish can also exert controls on fine sediment dynamics indirectly through their influence on other biogeomorphic agents. For example, bed disturbance and predation by fish may reduce the controls exerted by net-spinning caddisflies, macrophytes and algae ${ }^{189}$. Moreover, fish can have considerable impacts on the biogeochemical processes in rivers, ${ }_{-}$. For example, spawning migrations of anadromous fish (e.g. Oncorhynchus spp.) may becan be a-potentialn important source of marine-derived nitrogen and phosphorus to nutrient--poor habitats ${ }^{190,191}$, profoundly influencing the structure and function of further influencing aquatic and riparian biotaaquatic and terrestrial ecosystems ${ }^{185}$.

\section{CONTROLS ON ECOLOGICAL RESPONSES TO FINE SEDIMENT}

Whilst the impacts of excess fines on biota can be pervasive ${ }^{7-10}$ not all communities will be equally sensitive. In particular, the functional traits of the local biotic community, as well as those of the species comprising the regional species pool, will constrain the ecological response. Response traits determine 
an individual's ability to survive in different environmental conditions through characteristics that promote resistance and resilience to disturbances. Typically, such traits include information on morphology, phenology, behaviour and resource use ${ }^{192,193}$. Below we identify some of the major traits that are commonly associated with responses to fines (Table 1) and put them into context with biogeographic processes.

Table 1 - Traits involved in the effect of biota on fine sediment dynamics and the response of biota to excess fine sediment.

\begin{tabular}{|c|c|c|}
\hline $\begin{array}{l}\text { Taxonomic } \\
\text { group }\end{array}$ & Effect traits & Response traits \\
\hline All biota & & - Dispersal capacity \\
\hline Biofilms & $\begin{array}{l}\text { - Extracellular polymeric } \\
\text { substance (EPS) production } \\
\text { - Colony structure } \\
\text { - Growth rate }\end{array}$ & $\begin{array}{l}\text { - Colony structure } \\
\text { - Motility } \\
\text { - Size and shape } \\
\text { - Cell wall structure (rigidity) } \\
\text { - Photosynthetic capacity }\end{array}$ \\
\hline Plants & $\begin{array}{l}\text { - Shoot density } \\
\text { - Shoot and root structure } \\
\text { - Shoot flexibility }\end{array}$ & $\begin{array}{l}\text { - Fecundity } \\
\text { - Asexual (vegetative) reproduction } \\
\text { - Dispersal mode (hydrochory, anemochory) } \\
\text { - Reproductive timing } \\
\text { - Growth rate } \\
\text { - Shoot flexibility in high-flow periods } \\
\text { - Root structure and binding capacity }\end{array}$ \\
\hline Invertebrates & $\begin{array}{l}\text { - Feeding behaviour } \\
\text { - Burrowing activity } \\
\text { - Construction of feeding and } \\
\text { protective structures (e.g. } \\
\text { nets, cases) } \\
\text { - Body size }\end{array}$ & $\begin{array}{l}\text { - Feeding mode and diet } \\
\text { - Body size and shape } \\
\text { - Respiration mode } \\
\text { - Locomotion (e.g. burrowing, crawling) } \\
\text { - Reproduction mode (e.g. parental care, } \\
\text { oviviparity) } \\
\text { - Reproductive timing } \\
\text { - Voltinism (number of generations per year) }\end{array}$ \\
\hline
\end{tabular}




\section{Controls on ecological responses: Biogeography}

In rivers, the spatial distribution of organisms is highly dependent on the dendritic network structure ${ }^{194}$. Thus, at a broad level, ecological responses to fine sediment depend on the location of the site under consideration, as well as the topology and connectivity of the whole network ${ }^{195}$. The responses will also depend on the spatial structure of populations present within the network; if a population can be divided into subpopulations connected via dispersal, we may call it a 'metapopulation'196.

'Metacommunity' theory extends this idea to the community level by incorporating the effects of species sorting ('environmental filtering ${ }^{\prime 197}$ ) and biotic interactions ${ }^{198}$. The theory, as applied to river networks, predicts systematic variation in the forces driving community assembly with stream order (Figure 4). All else being equal, the impacts of stressors such as fine sediment are predicted to reduce alpha diversity in headwaters, where colonisation of adapted species and phenotypes adapted to stress caused by excess fine sediment is limited. Mid-basin locations, on the other hand, are expected to exhibit high rates of turnover in species composition, as efficient species sorting leads to rapid selection of adapted taxa from the species pool. Further downstream, the effects of the stressor are predicted to be dampened by the influx of organisms from upstream, to some extent regardless of the environment. Superimposed onto this trend is a natural tendency for the importance of fine particulate matter as a basal resource to increase downstream through the river network ${ }^{199}$. Fine sediment storage dynamics in high order river-floodplain systems are also tightly linked to flood pulses that are relatively predictable compared to events in low order streams ${ }^{200}$. These spatial patterns are further complicated by the discontinuities in fluxes of matter and energy caused by riverine barriers such as dams ${ }^{201}$.

(a) Dominant community assembly processes

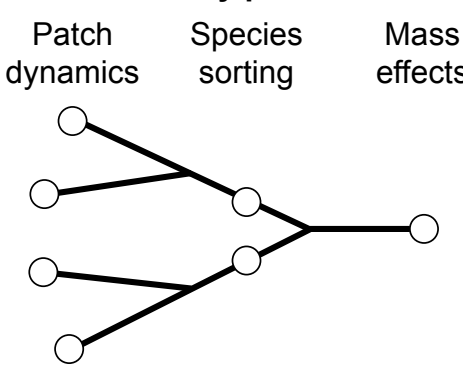

(b)

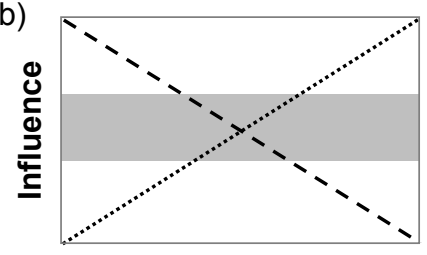

\section{Stream order}

- - Demographic stochasticity

...... Dispersal (mass effects)

Species sorting 
Figure 4 - Metacommunity theory predicts patterns in dominant community assembly processes in river networks (a) due to variation in spatial, environmental and demographic influences with stream order (b), with implications for ecosystem responses to stressors. Headwater communities are likely to follow the patch dynamics paradigm, whereby local species diversity is limited by dispersal and community structure becomes a function of stochastic demographic processes involving local extinction and colonisation ${ }^{198}$. The structure of lower mainstem communities is predicted to more closely resemble the regional species pool since high dispersal rates drown out the influence of the local environment through 'mass effects' ${ }^{198}$. In mid-basin locations, species sorting or 'environmental filtering'197 is made possible as the influence of dispersal is at an optimal level to allow for efficient niche-based

$$
\text { processes }^{202} \text {. }
$$

Whilst metacommunity theory provides a useful lens with which to study ecological responses to stressors, there are other regional-scale factors involved. Among these are biogeographical factors linked to the size of the species pool ${ }^{203}$. Relative to the number of taxa found at a given site, larger species pools are likely to contain species better adapted to a given stressor. Sites that are more saturated with respect to the species pool, on the other hand, will have less potential for adaptation. In the former case, high rates of turnover would be expected, whereas in the saturated case greater reductions in alpha (local) diversity are likely to ensue. These tendencies are further dependent on the traits expressed by taxa in the local assemblage and the wider species pool. In particular, the dispersal capacities of the regional fauna will, to a large extent, influence the relationship between the species pool, the local assemblage and stressor-driven changes ${ }^{204}$. In general, a weaker dispersing taxon will be less likely to colonise a newly suitable habitat patch after some environmental change, the likelihood also being contingent on the distance of established populations of that taxon from the impacted site ${ }^{205}$. Species pools are thus best represented as species- and site- specific probabilistic functions ${ }^{206}$. We consider other important traits controlling ecological responses below.

\section{Controls on ecological responses: Biofilm traits}

Biofilms comprise a mixture of heterotrophic (e.g. fungi, bacteria, protozoa) and autotrophic (e.g. cyanobacteria, algae, chemosynthetic bacteria) organisms, with many of the latter highly dependent on light. As such, the attenuation of light caused by increased sediment loads (either suspended or deposited) adversely affects the photosynthetic component of biofilms ${ }^{207}$, shifting the balance of these two traits, and thus the net primary production of affected biofilms ${ }^{208-211}$. For the sessile photosynthetic components, the absence of light caused by burial beneath depositing sediment can be catastrophic and the only option can be to produce resting stages to endure the period until erosion brings them to the surface once more. However, for motile taxa (e.g. raphid diatoms, ciliates, flagellates) shading from deposited fine sediment may not present a substantial problem, as they can move to higher light intensities at the streambed surface ${ }^{212,213}$. Hence, diatom assemblages tend to become dominated by motile taxa where rates of deposition of fine sediments are high ${ }^{214-216}$, although this trait (motility) may offer benefits under other conditions (e.g. nutrient rich conditions) such that the relationship with fine sediment is not straightforward ${ }^{217}$. 
The fact that deposited fine sediments are relatively unstable (compared with larger particles) renders them unsuitable for the attachment of long-lived sedentary species, particularly slow-growing and chain-forming taxa, pushing assemblages towards rapidly growing, single celled taxa. Whilst the lack of stability tends to result in reduced diatom taxon richness and biomass compared with more stable sediments ${ }^{218,219}$, patch disturbance history has a large influence on the development of biofilm communities $^{220}$. In turn, those taxa that exude mucilage are favoured, at least initially, as they tend to stabilise sediments (see discussion on EPS above).

The risk of being dislodged ${ }^{221}$ or suffering undergoing physical damage ${ }^{222}$ from suspended and particularly saltating sediment particles further selects against tall taxa (chain forming, filamentous, stalked and upright forms), and pushes communities towards adpressed forms and those that strongly adhere to the substrate (e.g. with mucilage pads), influencing traits associated with both growth form and attachment. More robust cell walls (e.g. thick walls, heavy silicification, costae) enable taxa to withstand physical damage. As such, species with thicker, more rigid cells walls are selected for where the suspended and saltating loads of inorganic sediment are high ${ }^{223}$. However, even these species are lost if disturbance is frequent ${ }^{224}$. Under more benign conditions, rapid growth rates may compensate for losses, with associated traits such as nutrient affinity being more apparent where deposited fine sediments are abundant ${ }^{217}$.

\section{Controls on ecological responses: Plant traits}

River engineer plants possess important traits that allow them to establish and persist in riverine and riparian environments ${ }^{9,225}$. These traits include: (i) an ability to reproduce vegetatively, both to colonise new patches and to extend and consolidate patches once established; (ii) an ability to grow rapidly in order to maximise their chances of becoming established, and to cope with burial by deposited material; (iii) above-ground biomass with sufficient rigidity (either as individual shoots or collectively as stands) and stand density to present a resistance to flow and, thus, retain sediment, but avoids breakage under higher flows; and (iv) below-ground biomass with sufficient strength and appropriate architecture to anchor plants and resist uprooting (e.g. stolons, rhizomes).

Reproduction and dispersal traits allow plant propagules to reach appropriate sites for germination and establishment. Both aquatic macrophyte and riparian tree species take advantage of sexual and asexual means to ensure reproductive success, with different reproductive strategies allowing successful annual recruitment at different locations. However, riparian and aquatic engineer species generally devote considerable resources to asexual reproduction, in particular through the production of adventitious roots from stem fragments, allowing them to expand their cover locally as well as colonising new areas $^{226}$. Asexual reproduction by riparian tree species largely depends on the ability of uprooted trees and wood fragments to sprout both roots and shoots once deposited. Some aquatic macrophyte species, particularly those with emergent growth forms (e.g. Sparganium erectum, Glyceria maxima), produce dense networks of rhizomes or stolons that support the spread of patches, as well as dispersal if the plant is fragmented, whilst others regenerate freely from stem fragments ${ }^{227}$. The development of adventitious roots, stolons and rhizomes allows plants to cope with burial and to consolidate the deposited material (e.g. ${ }^{126}$ ). Many aquatic plants and riparian shrubs (e.g. Salicaceae) develop such 
structures, which enter and reinforce aggrading sediments while maintaining reinforcement and erosion resistance in buried substrates (e.g. ${ }^{132}$ ). Furthermore, plants can exploit the nutrients available from deposited material by rooting into it: much of the organic material deposited in stands of Ranunculus penicillatus is remineralised and used for growth of the plant, further accentuating deposition ${ }^{228}$, a characteristic likely to be true of other species.

Once deposited, propagules of engineer plants germinate or sprout and typically grow rapidly to anchor themselves and support their survival in disturbed river environments. Rapid shoot and root growth is particularly important for species both to exploit opportunities for growth before disturbance removes them and to cope with burial. For example, field observations along the Tagliamento River, Italy, have recorded main shoot growth in Populus nigra, Salix alba and Salix eleagnos seedlings, cuttings and from uprooted, deposited trees of up to $3 \mathrm{~mm} \mathrm{day}^{-1}, 10 \mathrm{~mm}^{-1} \mathrm{day}^{-1}$ and $15 \mathrm{~mm} \mathrm{day}^{-1}$, respectively 229,230 . Furthermore, greenhouse experiments on cuttings of Salix eleagnos and Populus nigra have revealed vertical root penetration of 27 and $15 \mathrm{~mm}^{-1} \mathrm{y}^{-1}$ respectively for sand substrates, and 20 and $10 \mathrm{~mm}$ day 1 , respectively for gravel substrates under a water table falling at $30 \mathrm{~mm}$ day ${ }^{-1}{ }^{231}$. Many aquatic plants avoid disturbance during winter and spring high flows by producing dense networks of rhizomes that persist through the winter, anchoring the plants and reinforcing penetrated sediments, whilst following an annual above-ground growth cycle whereby shoots emerge in the spring. Peak biomass is reached in mid to late summer and then senesce during autumn, leaving little (if any) above-ground biomass exposed during winter high flow events (e.g. ${ }^{126,232,233}$ ). During the growth period, species succession in aquatic plant stands is closely related to the ability to outpace the rate of deposition, favouring species with fast growth rates (including the ability to exploit nutrients from deposited material) and the capacity to adopt an emergent strategy $y^{234,235}$.

As stated above, the extent to which plants retain sediment is related to the resistance they present to the flow of water. However, this resistance coupled with the instability of deposited sediment increases the likelihood of plants being uprooted, particularly during flood conditions. The prevalence of traits associated with rapid growth, either to cope with burial, patch instability or to exploit nutrients from deposited material, together with a high dependency on vegetative growth, leads to a plant trait syndrome similar to that seen in highly competitive taxa typical of nutrient rich conditions ${ }^{236}$. Hence, it is not surprising that taxa indicative of high nutrient conditions thrive in rivers with large amounts of deposited sediment ${ }^{9,237}$.

\section{Controls on ecological responses: Invertebrate traits}

Excess fine sediment is widely acknowledged to have deleterious effects on the structure and function of invertebrate communities $8,54,60,238$. Substrates with a high volume of fines typically support homogenous communities that are dominated by relatively few taxa $a^{47,239-241}$. The composition of invertebrate taxa present in different environmental settings is strongly constrained by the functional traits they possess ${ }^{242}$, resulting in variable tolerance or sensitivity to excess fines ${ }^{243,244}$.

High sediment loads reduce the quality and availability of trophic resources which may reduce feeding efficiency, most notably for shredders ${ }^{244-247}$. Other feeding modes, including algal scrapers and filter 
feeders, also demonstrate some sensitivity to fine sediment ${ }^{248-250}$ but the effect lacks consistency, suggesting that other factors interact with these traits to determine the response. Increasing infiltration of fines fills interstitial pore spaces and reduces dissolved oxygen concentrations, limiting the ability of many taxa to persist due to their body size, shape and respiratory requirements ${ }^{251,252}$. As such, streambeds subjected to high levels of deposition and infiltration are frequently characterised by taxa with small body sizes and lower densities of interstitial dwellers $60,246,253,254$.

Locomotion traits may also be implicated in the impacts of fine sediment deposition on invertebrate communities. Burrowing taxa associated with depositional habitats are well adapted to fine sediment, whilst crawlers may be adversely affected during deposition events due to their reduced locomotive capacity ${ }^{251,255-257}$. Species with certain respiration modes can also be highly sensitive to fine sediment transported in the suspended or saltating load. Delicate gill structures, for example, may become physically abraded or clogged by fine sediment, limiting the exchange of oxygen ${ }^{258,259}$. Reproduction mode may also exert a strong control over which taxa are able to persist in substrates with high fine sediment content. Unattended eggs deposited onto the stream bed, for instance, may become smothered or abraded by fine sediment ${ }^{260}$. As a result, the prevalence of ovoviviparity, as found in diverse taxa (e.g. Sphaerium spp., Asellus aquaticus, Cloëon spp.), may increase in streams subjected to high sediment loads $246,261,262$. Voltinism also influences a taxon's ability to recover from disturfubances such as those wrought by excess fine sediment, with mutivolitine taxa recovering more rapidly compared to univoltine taxa ${ }^{257,263}$. This resilience to disturbance is associated with a trait syndrome that includes small body sizes and short life cycle lengths.

Despite trait-based ecology gaining increasing recognition for its ability to predict tolerance and sensitivity to a range of stressors, further research is required to strengthen the mechanistic basis behind the use of invertebrate traits in fine sediment-specific biomonitoring applications ${ }^{244}$. The consideration of traits should be evaluated with caution as a number of recent studies have reported inconsistent responses of invertebrates to fine sediment deposition $47,246,254,257$. Traits are unlikely to act in isolation but rather as combinations of traits describing life-history strategies of varying resistance and resilience to stressors such as fine sediment ${ }^{47,264}$. Furthermore, the timing of fine sediment events relative to a taxon's life-cycle will play an important role ${ }^{254}$ as will a taxon's preferred habitat and substrate composition ${ }^{244}$.

\section{Controls on ecological responses: Fish traits}

A range of fish traits have been implicated in community responses to fine sediment carried in suspension, in the saltating load, surface deposited or infiltrated ${ }^{7}$. Well-documented, direct negative impacts include the clogging and abrasion of soft tissues, especially gills ${ }^{265,266}$. Fish adaptations to enhance resistance to this include increased mucus secretion and a thickening of the gill epithelium ${ }^{267}$. However, under high SSC, mucus secretions can result in increased susceptibility to clogging of the gill surface and ultimately suffocation of the fish ${ }^{268}$. Further adaptations to living in turbid conditions are associated with the mechanosensory system, including development of the lateral line system and inner ear used to sense hydrodynamic cues, specialised reflective structures in the eye, and tactile and olfactory senses ${ }^{269-271}$. 
By far the most well-known impact of deposited and infiltrated fine sediment is the smothering of salmon redds ${ }^{49}$. However, the majority of freshwater fish species are not lithophilous. Phytophilous species are also likely to be indirectly impacted due to reductions in submerged vegetation under high fine sediment loadings, whereas reproduction in psammophilous taxa may be favoured if deposition is associated mainly with the sand fraction. Some species avoid the potential impacts of fine sediment on eggs by ovipositing on riparian vegetation at high flows, with eggs developing out of the water until the next high flow (e.g. Galaxias argentus ${ }^{272}$ ). The timing of life-history events relative to periods of high fine sediment loadings can play an important role in fish responses to fines. In many temperate systems, for example, fine sediment accumulation in spawning gravels will likely be highest during the summer baseflow period ${ }^{54}$. Spawning outside of this period is therefore one way to avoid the most deleterious impacts on eggs and embryos ${ }^{7}$.

Herbivorous fish are indirectly impacted by reductions in submerged macrophyte abundance and changes in plant species composition due to light attenuation and abrasive forces of suspended and saltating sediment, as well as the deposition of fine material on plant surfaces, which reduces plant growth and nutritional quality ${ }^{9,273}$. This generates further impacts on other species by reducing or changing the nature of available cover. Zooplankton feeders may benefit from enhanced foraging efficiency under high SSC as their prey congregate near the water surface ${ }^{274}$, although the reduced visibility associated with such conditions is likely to result in net-negative impacts on feeding ${ }^{275}$. Similarly, high turbidity events may enhance prey availability due to increased invertebrate drift rates. However, foraging efficiency for drift-feeding fish decline under even mildly turbid conditions ${ }^{276}$ and, in the long-term, invertebrate drift events in response to high SSC are likely to contribute to a change in invertebrate community composition which would negatively impact invertivorous fish ${ }^{277}$.

\section{Conclusion}

The presence of excess fine sediment in rivers is a major reason for failure of EU member states to achieve Good Ecological Status under the Water Framework Directive. In this context, we have presented a broad synthesis of current understanding in the belief that this can help to drive the production of new scientific knowledge and inspire management innovation. In particular, we have highlighted biogeomorphic processes that control the transport and storage of fine sediment, and the mechanisms by which this elicits ecological responses and feedbacks. The fine sediment 'problem'11 represents a major challenge for applied environmental science worldwide but progress is being made towards a more complete understanding of the physical and biological processes involved. This progress should be maintained and accelerated by continuing the open dialogue between management agencies and scientists working within the broad disciplines of ecology, hydraulic engineering, fluvial geomorphology and hydrochemistry. In Sidebar 1, we briefly describe the outcomes of a workshop intended to address this need. Based on the experiences of environmental managers present, the workshop participants identified the most urgent knowledge gaps. These ranged from the collation of existing data and case studies to the investigation of responses to fine sediment at the population and whole ecosystem levels. In this wayThrough initiatives such as this, key management challenges, scientific research priorities, and the production of new knowledge can all inform and shape one another (see sidebar). 


\section{SIDEBAR 1 - SUPPORTING GOOD ECOLOGICAL STATUS THROUGH RESEARCH}

A British Ecological Society-funded workshop in July 2017 brought together early career researchers working on fine sediment internationally along with UK-based environmental managers and senior scientists in the field to discuss how to support the achievement of GES through research. The discussions indicated that fine sediment-related failures to achieve GES in England and Wales are largely due to agricultural and rural land management, followed by urbanisation and transport. Measures to address the problem for point and diffuse sources exist but there are gaps in the evidence, including information on the risk of further deterioration, impacts on protected areas, and the interaction of fine sediment with other pressures. More catchment-scale data is needed to inform management, along with greater collation of existing case studies. Evidence is required for the effectiveness of alternative measures under future climate change and socio-economic scenarios. Further development and testing of pressure-specific biomonitoring metrics will help to link ecological changes to causal factors.

Specifically, environmental managers needed answers to the following questions:

- What are sediment yields and dynamics in rivers under different land use and management scenarios?

- $\quad$ How do we define 'natural' sediment conditions in aquatic ecosystems?

- $\quad$ How much do we need to reduce the sediment input by to see an ecological benefit?

- $\quad$ How can we evaluate the benefits of reducing excess fine sediment in rivers?

- What are the impacts of invasive species on sediment regimes? - especially plants such as Himalayan balsam and burrowing animals such as crayfish.

- $\quad$ Are there thresholds of fine sediment loadings beyond which ecological impacts are more severe?

- $\quad$ How can the risks of fine sediment impacts on sensitive species, such as the pearl mussels (Margaritifera margaritifera), be assessed most effectively?

- Which management measures are most cost-effective?

- What are the risks of dispersive dredging from contaminated sediments?

- What is the role of fine sediment dynamics in the transport of microplastics?

\section{Acknowledgments}

This paper resulted from a workshop funded by the British Ecological Society ("Early careers, fine sediment and hydroecology: Supporting Good Ecological Status through research", July 2017). We would like to thank early career scientists who participated in the workshop but did not contribute directly to 
the preparation of this paper, namely Leticia Miguel (Environment Agency), Zarah Pattison (University of Stirling), Anna Lavelle and Eleanore Heasley (King's College London), James Smith (Loughborough University), Hazel Wilson (University of Nottingham), Matt Turley (University of Brighton), Tea Basic and Catherine Gutmann Roberts (Bournemouth University), and George Bunting (University of Worcester).

Figures and Tables

References

1. Collins AL, Anthony SG, Hawley J, Turner T. Predicting potential change in agricultural sediment inputs to rivers across England and Wales by 2015. Mar Freshw Res [Internet]. 2009 [cited 2018 Jul 26];60(7):626-37. Available from: http://www.publish.csiro.au/mf/mf08033

2. Zhang Y, Collins AL, Murdoch N, Lee D, Naden PS. Cross sector contributions to river pollution in England and Wales: Updating waterbody scale information to support policy delivery for the Water Framework Directive. Environ Sci Policy [Internet]. 2014 Oct [cited 2018 Jul 4];42:16-32. Available from: http://linkinghub.elsevier.com/retrieve/pii/S1462901114000823

3. Naden PS, Murphy JF, Old GH, Newman J, Scarlett P, Harman M, et al. Understanding the controls on deposited fine sediment in the streams of agricultural catchments. Sci Total Environ [Internet]. 2016 Mar 15 [cited 2018 Jul 4];547:366-81. Available from: https://www.sciencedirect.com/science/article/pii/S004896971531233X

4. Walling DE, Collins AL. Fine sediment transport and management. In: River science : research and management for the 21st Century [Internet]. Wiley Blackwell; 2016 [cited 2018 Jul 4]. p. 37-60. Available from: https://www.wiley.com/engb/River+Science\%3A+Research+and+Management+for+the+21st+Century-p-9781119994343

5. Boano F, Revelli R, Ridolfi L. Water and solute exchange through flat streambeds induced by large turbulent eddies. J Hydrol [Internet]. 2011 May 25 [cited 2018 Jul 30];402(3-4):290-6. Available from: https://www.sciencedirect.com/science/article/pii/S0022169411002034

6. Atkinson CL, Allen DC, Davis L, Nickerson ZL. Incorporating ecogeomorphic feedbacks to better understand resiliency in streams: A review and directions forward. Geomorphology [Internet]. 2017 [cited $2018 \mathrm{Jul}$ 30]; Available from:

https://www.sciencedirect.com/science/article/pii/S0169555X17300090

7. Kemp P, Sear D, Collins A, Naden P, Jones I. The impacts of fine sediment on riverine fish. Hydrol Process [Internet]. 2011 May 30 [cited 2018 Jul 30];25(11):1800-21. Available from: http://doi.wiley.com/10.1002/hyp.7940

8. Jones JI, Murphy JF, Collins AL, Sear DA, Naden PS, Armitage PD. The Impact Of Fine Sediment On Macro-Invertebrates. River Res Appl [Internet]. 2012 Oct [cited 2018 Jul 30];28(8):1055-71. Available from: http://doi.wiley.com/10.1002/rra.1516

9. Jones JI, Collins AL, Naden PS, Sear DA. The relationship between fine sediment and macrophytes in rivers. River Res Appl [Internet]. 2012 Sep [cited $2018 \mathrm{Jul}$ 30];28(7):1006-18. Available from: http://doi.wiley.com/10.1002/rra.1486

10. Jones JI, Duerdoth CP, Collins AL, Naden PS, Sear DA. Interactions between diatoms and fine 
sediment. Hydrol Process [Internet]. 2014 Jan 30 [cited 2018 Jul 30];28(3):1226-37. Available from: http://doi.wiley.com/10.1002/hyp.9671

11. Wharton $\mathrm{G}$, Mohajeri SH, Righetti $\mathrm{M}$. The pernicious problem of streambed colmation: a multidisciplinary reflection on the mechanisms, causes, impacts, and management challenges. Wiley Interdiscip Rev Water [Internet]. 2017 Sep [cited 2018 Jul 11];4(5):e1231. Available from: http://doi.wiley.com/10.1002/wat2.1231

12. Collins AL, Zhang YS, Duethmann D, Walling DE, Black KS. Using a novel tracing-tracking framework to source fine-grained sediment loss to watercourses at sub-catchment scale. Hydrol Process [Internet]. 2013 Mar 15 [cited 2018 Jul 30];27(6):959-74. Available from: http://doi.wiley.com/10.1002/hyp.9652

13. Nosrati K, Collins AL, Madankan M. Fingerprinting sub-basin spatial sediment sources using different multivariate statistical techniques and the Modified MixSIR model. Catena [Internet]. 2018 [cited $2018 \mathrm{Jul} 30$ ];164:32-43. Available from:

https://www.sciencedirect.com/science/article/pii/S0341816218300031

14. Collins AL, Williams L, Zhang YS, Marius M, Dungait JAJ, Smallman DJ, et al. Catchment source contributions to the sediment-bound organic matter degrading salmonid spawning gravels in a lowland river, southern England. Sci Total Environ [Internet]. 2013 Jul 1 [cited 2018 Jul 30];456457:181-95. Available from: https://www.sciencedirect.com/science/article/pii/S0048969713003987

15. Collins AL, Walling DE, Stroud RW, Robson M, Peet LM. Assessing damaged road verges as a suspended sediment source in the Hampshire Avon catchment, southern United Kingdom. Hydrol Process [Internet]. 2010 Apr 30 [cited 2018 Jul 30];24(9):1106-22. Available from: http://doi.wiley.com/10.1002/hyp.7573

16. Collins AL, Zhang YS, Hickinbotham R, Bailey G, Darlington S, Grenfell SE, et al. Contemporary fine-grained bed sediment sources across the River Wensum Demonstration Test Catchment, UK. Hydrol Process [Internet]. 2013 Mar 15 [cited 2018 Jul 30];27(6):857-84. Available from: http://doi.wiley.com/10.1002/hyp.9654

17. Edwards KJ, Whittington G. Lake sediments, erosion and landscape change during the Holocene in Britain and Ireland. Catena [Internet]. $2001 \mathrm{Jan} 20$ [cited $2018 \mathrm{Jul}$ 30];42(2-4):143-73. Available from: https://www.sciencedirect.com/science/article/pii/S0341816200001363

18. Chiverrell RC, Oldfield F, Appleby PG, Barlow D, Fisher E, Thompson R, et al. Evidence for changes in Holocene sediment flux in Semer Water and Raydale, North Yorkshire, UK. Geomorphology [Internet]. 2008 Aug 1 [cited 2018 Jul 30];100(1-2):70-82. Available from: https://www.sciencedirect.com/science/article/pii/S0169555X08001712

19. Macklin MG, Jones AF, Lewin J. River response to rapid Holocene environmental change: evidence and explanation in British catchments. Quat Sci Rev [Internet]. 2010 Jun 1 [cited 2018 Jul 30];29(13-14):1555-76. Available from: https://www.sciencedirect.com/science/article/pii/S0277379109002030

20. Foster IDL, Collins AL, Naden PS, Sear DA, Jones JI, Zhang Y. The potential for paleolimnology to determine historic sediment delivery to rivers. J Paleolimnol [Internet]. 2011 Feb 20 [cited 2018 
Jul 30];45(2):287-306. Available from: http://link.springer.com/10.1007/s10933-011-9498-9

21. Collins AL, Zhang Y. Exceedance of modern "background" fine-grained sediment delivery to rivers due to current agricultural land use and uptake of water pollution mitigation options across England and Wales. Environ Sci Policy [Internet]. 2016;61:61-73. Available from: https://www.sciencedirect.com/science/article/pii/S1462901116300740

22. Frostick LE, Lucas PM, Reid I. The infiltration of fine matrices into coarse-grained alluvial sediments and its implications for stratigraphical interpretation. J Geol Soc London [Internet]. 1984 [cited $2018 \mathrm{Jul} 30$ ];141(6):955-65. Available from: http://jgs.lyellcollection.org/cgi/doi/10.1144/gsjgs.141.6.0955

23. Lisle TE. Sediment transport and resulting deposition in spawning gravels, north coastal California. Water Resour Res [Internet]. 1989 Jun [cited 2018 Jul 30];25(6):1303-19. Available from: http://doi.wiley.com/10.1029/WR025i006p01303

24. Sear DA. Fine sediment infiltration into gravel spawning beds within a regulated river experiencing floods: Ecological implications for salmonids. Regul Rivers Res Manag [Internet]. 1993 Dec [cited 2018 Jul 30];8(4):373-90. Available from: http://doi.wiley.com/10.1002/rrr.3450080407

25. Owens PN, Batalla RJ, Collins AJ, Gomez B, Hicks DM, Horowitz AJ, et al. Fine-grained sediment in river systems: environmental significance and management issues. River Res Appl [Internet]. 2005 Sep [cited $2018 \mathrm{Jul} 30$ ];21(7):693-717. Available from: http://doi.wiley.com/10.1002/rra.878

26. Walling DE, Moorehead PW. The particle size characteristics of fluvial suspended sediment: an overview. In: Hydrobiologia [Internet]. Dordrecht: Springer Netherlands; 1989 [cited 2018 Jul 30]. p. 125-49. Available from: http://www.springerlink.com/index/10.1007/978-94-009-2376-8_12

27. Droppo IG. Rethinking what constitutes suspended sediment. Hydrol Process [Internet]. 2001 Jun 30 [cited $2018 \mathrm{Jul}$ 30];15(9):1551-64. Available from: http://doi.wiley.com/10.1002/hyp.228

28. Wohl E, Bledsoe BP, Jacobson RB, Poff NL, Rathburn SL, Walters DM, et al. The natural sediment regime in rivers: Broadening the foundation for ecosystem management. Bioscience [Internet]. 2015 Apr 1 [cited $2018 \mathrm{Jul}$ 30];65(4):358-71. Available from: http://academic.oup.com/bioscience/article/65/4/358/254680/The-Natural-Sediment-Regimein-Rivers-Broadening

29. Petts GE, Gurnell AM. Dams and geomorphology: Research progress and future directions. Geomorphology [Internet]. 2005 Oct 1 [cited 2018 Jul 30];71(1-2):27-47. Available from: https://www.sciencedirect.com/science/article/pii/S0169555X05000875

30. Crosa G, Castelli E, Gentili G, Espa P. Effects of suspended sediments from reservoir flushing on fish and macroinvertebrates in an alpine stream. Aquat Sci [Internet]. 2009 Jan 13 [cited $2018 \mathrm{Jul}$ 30];72(1):85-95. Available from: http://link.springer.com/10.1007/s00027-009-0117-z

31. Einstein HA. Deposition of suspended particles in a gravel bed. J Hydraul Div [Internet]. 1968 [cited $2018 \mathrm{Jul}$ 30];1197-205. Available from:

http://cedb.asce.org/CEDBsearch/record.jsp?dockey=0015321 
35. Elliott $\mathrm{AH}$, Brooks NH. Transfer of nonsorbing solutes to a streambed with bed forms: Theory. Water Resour Res [Internet]. 1997 Jan [cited 2018 Jul 30];33(1):123-36. Available from: http://doi.wiley.com/10.1029/96WR02783

36. Mathers KL, Wood PJ. Fine sediment deposition and interstitial flow effects on macroinvertebrate community composition within riffle heads and tails. Hydrobiologia [Internet]. 2016 Aug 31 [cited $2018 \mathrm{Jul} 30$ ];776(1):147-60. Available from: http://link.springer.com/10.1007/s10750-016-2748-0

37. Brunke M. Colmation and depth filtration within streambeds: Retention of particles in hypoheic interstices. Int Rev Hydrobiol [Internet]. 1999 [cited 2018 Jul 30];84(2):99-117. Available from: https://onlinelibrary.wiley.com/doi/abs/10.1002/iroh.199900014

38. Savant SA, Reible DD, Thibodeaux LJ. Convective transport within stable river sediments. Water Resour Res [Internet]. 1987 Sep [cited 2018 Jul 30];23(9):1763-8. Available from: http://doi.wiley.com/10.1029/WR023i009p01763

39. Packman Al, Salehin M, Zaramella M. Hyporheic Exchange with Gravel Beds: Basic Hydrodynamic Interactions and Bedform-Induced Advective Flows. J Hydraul Eng [Internet]. 2004 Jul [cited 2018 Jul 30];130(7):647-56. Available from: http://ascelibrary.org/doi/10.1061/\%28ASCE\%2907339429\%282004\%29130\%3A7\%28647\%29

40. Cardenas MB, Wilson JL, Zlotnik VA. Impact of heterogeneity, bed forms, and stream curvature on subchannel hyporheic exchange. Water Resour Res [Internet]. 2004 Aug [cited 2018 Jul 30];40(8). Available from: http://doi.wiley.com/10.1029/2004WR003008

41. Stewardson MJ, Datry $\mathrm{T}$, Lamouroux N, Pella H, Thommeret N, Valette L, et al. Variation in reachscale hydraulic conductivity of streambeds. Geomorphology [Internet]. 2016 [cited $2018 \mathrm{Jul}$ 30];259:70-80. Available from: https://www.sciencedirect.com/science/article/pii/S0169555X16300216

42. Casas-Mulet R, Lakhanpal G, Stewardson MJ. The relative contribution of near-bed vs. intragravel horizontal transport to fine sediment accumulation processes in river gravel beds. Geomorphology [Internet]. 2018 [cited 2018 Aug 6];303:299-308. Available from: https://www.sciencedirect.com/science/article/pii/S0169555X17305147

43. Manes C, Pokrajac D, McEwan I, Nikora V. Turbulence structure of open channel flows over 
permeable and impermeable beds: A comparative study. Phys Fluids [Internet]. 2009 Dec [cited 2018 Jul 30];21(12):1-12. Available from: http://aip.scitation.org/doi/10.1063/1.3276292

44. Casas-Mulet R, Alfredsen KT, McCluskey AH, Stewardson MJ. Key hydraulic drivers and patterns of fine sediment accumulation in gravel streambeds: A conceptual framework illustrated with a case study from the Kiewa River, Australia. Geomorphology [Internet]. 2017 [cited 2018 Jul 30];299:152-64. Available from: https://www.sciencedirect.com/science/article/pii/S0169555X17303380

45. Hassan MA, Tonina D, Beckie RD, Kinnear M. The effects of discharge and slope on hyporheic flow in step-pool morphologies. Hydrol Process [Internet]. 2015 Jan 30 [cited $2018 \mathrm{Jul}$ 30];29(3):419-33. Available from: http://doi.wiley.com/10.1002/hyp.10155

46. Murphy JF, Jones JI, Pretty JL, Duerdoth CP, Hawczak A, Arnold A, et al. Development of a biotic index using stream macroinvertebrates to assess stress from deposited fine sediment. Freshw Biol [Internet]. 2015 Oct 1 [cited 2018 Aug 6];60(10):2019-36. Available from: http://doi.wiley.com/10.1111/fwb.12627

47. Murphy JF, Jones JI, Arnold A, Duerdoth CP, Pretty JL, Naden PS, et al. Can macroinvertebrate biological traits indicate fine-grained sediment conditions in streams? River Res Appl [Internet]. 2017 Dec 1 [cited 2018 Aug 1];33(10):1606-17. Available from:

http://doi.wiley.com/10.1002/rra.3194

48. Sear DA, Jones JI, Collins AL, Hulin A, Burke N, Bateman S, et al. Does fine sediment source as well as quantity affect salmonid embryo mortality and development? Sci Total Environ [Internet]. 2016 Jan 15 [cited 2018 Aug 6];541:957-68. Available from: https://www.sciencedirect.com/science/article/pii/S0048969715308160

49. Sear DA, Pattison I, Collins AL, Smallman DJ, Jones JI, Naden PS. The magnitude and significance of sediment oxygen demand in gravel spawning beds for the incubation of salmonid embryos. River Res Appl [Internet]. 2017 Dec [cited 2018 Jul 30];33(10):1642-54. Available from: http://doi.wiley.com/10.1002/rra.3212

50. Von Bertrab MG, Krein A, Stendera S, Thielen F, Hering D. Is fine sediment deposition a main driver for the composition of benthic macroinvertebrate assemblages? Ecol Indic [Internet]. 2013 [cited $2018 \mathrm{Jul}$ 30];24:589-98. Available from: https://www.sciencedirect.com/science/article/pii/S1470160X12002920

51. Elbrecht V, Beermann AJ, Goessler G, Neumann J, Tollrian R, Wagner R, et al. Multiple-stressor effects on stream invertebrates: A mesocosm experiment manipulating nutrients, fine sediment and flow velocity. Freshw Biol [Internet]. 2016 [cited 2018 Jul 30];61(4):362-75. Available from: https://www.sciencedirect.com/science/article/pii/S0048969717320818

52. Davis SJ, Ó hUallacháin D, Mellander PE, Kelly AM, Matthaei CD, Piggott JJ, et al. Multiple-stressor effects of sediment, phosphorus and nitrogen on stream macroinvertebrate communities. Sci Total Environ [Internet]. 2018 [cited $2018 \mathrm{Jul}$ 30];637-638(May):577-87. Available from: https://doi.org/10.1016/j.scitotenv.2018.05.052

53. Kirk JTO. Effects of suspensoids (turbidity) on penetration of solar radiation in aquatic ecosystems. Hydrobiologia [Internet]. 1985 Jun [cited 2018 Jul 30];125(1):195-208. Available 
from: http://link.springer.com/10.1007/BF00045935

54. Wood PJ, Armitage PD. Biological effects of fine sediment in the lotic environment. Environ Manage [Internet]. 1997 Mar 1 [cited 2018 Jul 19];21(2):203-17. Available from: http://link.springer.com/10.1007/s002679900019

55. Paaijmans KP, Takken W, Githeko AK, Jacobs AFG. The effect of water turbidity on the nearsurface water temperature of larval habitats of the malaria mosquito Anopheles gambiae. Int J Biometeorol [Internet]. 2008 Nov 17 [cited 2018 Jul 30];52(8):747-53. Available from: http://link.springer.com/10.1007/s00484-008-0167-2

56. Veličković B. Colmation as one of the processes in interaction between the groundwater and surface water. Facta Univ - Ser Archit Civ Eng [Internet]. 2005 [cited 2018 Jul 30];3(2):165-72. Available from: http://scindeks.ceon.rs/article.aspx?artid=0354-46050502165V

57. Soulsby C, Youngson AF, Moir HJ, Malcolm IA. Fine sediment influence on salmonid spawning habitat in a lowland agricultural stream: A preliminary assessment. Sci Total Environ [Internet]. 2001 [cited $2018 \mathrm{Jul} 30$ ];265(1-3):295-307. Available from: https://www.sciencedirect.com/science/article/pii/S0048969700006720

58. Greig SM, Sear DA, Carling PA. A review of factors influencing the availability of dissolved oxygen to incubating salmonid embryos. Hydrol Process [Internet]. 2007 Jan 30 [cited 2018 Jul 30];21(3):323-34. Available from: http://doi.wiley.com/10.1002/hyp.6188

59. Chapman JM, Proulx CL, Veilleux MAN, Levert C, Bliss S, André MÈ, et al. Clear as mud: A metaanalysis on the effects of sedimentation on freshwater fish and the effectiveness of sedimentcontrol measures. Water Res [Internet]. 2014 [cited 2018 Jul 30];56:190-202. Available from: https://www.sciencedirect.com/science/article/pii/S0043135414001754

60. Jones I, Growns I, Arnold A, McCall S, Bowes M. The effects of increased flow and fine sediment on hyporheic invertebrates and nutrients in stream mesocosms. Freshw Biol [Internet]. $2015 \mathrm{Apr}$ 1 [cited 2018 Aug 2];60(4):813-26. Available from: http://doi.wiley.com/10.1111/fwb.12536

61. Emerson D, Revsbech NP. Investigation of an iron-oxidizing microbial mat community located near Aarhus, Denmark: Field studies. Appl Environ Microbiol [Internet]. 1994 Nov 1 [cited 2018 Jul 30];60(11):4022-31. Available from: http://www.ncbi.nlm.nih.gov/pubmed/16349433

62. Waters TF. Sediment in Streams: Source, Biological Effects and Control. American Fisheries Society monograph (USA). Bethesda: American Fisheries Society; 1995. 251 p.

63. Westrich B, Förstner U. Sediment dynamics and pollutant mobility in rivers: an interdisciplinary approach [Internet]. Berlin: Springer; 2007 [cited 2018 Jul 30]. Available from: https://books.google.co.uk/books?hl=en\&lr=\&id=UxbcOmW9pvQC\&oi=fnd\&pg=PA1\&dq=Sedime $\mathrm{nt}+$ Dynamics+and+Pollutant+Mobility+in+Rivers:+An+Interdisciplinary+Approach\&ots=t2X5okd4 S8\&sig=5Z70OxwbjjV0qTO63RQH4G6lvKo\#v=onepage\&q=Sediment Dynamics and Pollutant Mobili

64. Ji Z. Hydrodynamics and Water Quality: Modeling Rivers, Lakes, and Estuaries. Second ed. Hoboken: John Wiley \& Sons; 2017.

65. Hossain HMZ, Kawahata H, Roser BP, Sampei Y, Manaka T, Otani S. Geochemical characteristics 
of modern river sediments in Myanmar and Thailand: Implications for provenance and weathering. Chemie der Erde - Geochemistry [Internet]. 2017 [cited 2018 Jul 30];77(3):443-58. Available from: https://www.sciencedirect.com/science/article/pii/S0009281916302343

66. Huang Y, Zhang D, Xu Z, Yuan S, Li Y, Wang L. Effect of overlying water pH, dissolved oxygen and temperature on heavy metal release from river sediments under laboratory conditions. Arch Environ Prot [Internet]. 2017 [cited 2018 Jul 30];43(2):28-36. Available from: https://www.degruyter.com/view/j/aep.2017.43.issue-2/aep-2017-0014/aep-2017-0014.xml

67. Liikanen, ALiikanen, A., T. Murtoniemi, H. Tanskanen, T. Väisänen and PJM 2002. E of T and OA on GG and ND in S of a EM-BL greenhouse gas and nutrient dynamics in sediment of. B 59:269286., Murtoniemi T, Tanskanen H, Väisänen T, Martikainen PJ. Effects of Temperature and Oxygen Availability on Greenhouse Gas and Nutrient Dynamics in Sediment of a Eutrophic MidBoreal Lake greenhouse gas and nutrient dynamics in sediment of. Biogeochemistry [Internet]. 2002 [cited $2018 \mathrm{Jul}$ 30];59(3):269-86. Available from: https://link.springer.com/article/10.1023/A:1016015526712

68. Wu Y, Wen Y, Zhou J, Wu Y. Phosphorus release from lake sediments: Effects of $\mathrm{pH}$, temperature and dissolved oxygen. KSCE J Civ Eng [Internet]. 2014 Jan 27 [cited 2018 Aug 2];18(1):323-9. Available from: http://link.springer.com/10.1007/s12205-014-0192-0

69. Tsai L, Ho ST, Yu KC. Correlations of extractable heavy metals with organic matters in contaminated river sediments. Water Sci Technol [Internet]. 2003 [cited 2018 Jul 30];47(9):1017. Available from: https://iwaponline.com/wst/article-abstract/47/9/101/10564

70. Fojut TL, Young TM. Pyrethroid sorption to Sacramento River suspended solids and bed sediments. Environ Toxicol Chem [Internet]. 2011 Apr [cited 2018 Jul 30];30(4):787-92. Available from: http://doi.wiley.com/10.1002/etc.448

71. Duong HT, Kadokami K, Pan S, Matsuura N, Nguyen TQ. Screening and analysis of 940 organic micro-pollutants in river sediments in Vietnam using an automated identification and quantification database system for GC-MS. Chemosphere [Internet]. 2014 [cited 2018 Jul 30];107:462-72. Available from: http://dx.doi.org/10.1016/j.chemosphere.2014.01.064

72. Van Leussen W. Aggregation of particles, settling velocity of mud flocs a review. In: Physical processes in estuaries [Internet]. Berlin, Heidelberg: Springer Berlin Heidelberg; 1988 [cited 2018 Jul 31]. p. 347-403. Available from: http://link.springer.com/10.1007/978-3-642-73691-9_19

73. Bainbridge ZT, Wolanski E, Álvarez-Romero JG, Lewis SE, Brodie JE. Fine sediment and nutrient dynamics related to particle size and floc formation in a Burdekin River flood plume, Australia. Mar Pollut Bull [Internet]. 2012 [cited 2018 Jul 31];65(4-9):236-48. Available from: https://www.sciencedirect.com/science/article/pii/S0025326X12000665

74. Casas-Ruiz JP, Catalán N, Gómez-Gener L, von Schiller D, Obrador B, Kothawala DN, et al. A tale of pipes and reactors: Controls on the in-stream dynamics of dissolved organic matter in rivers. Limnol Oceanogr [Internet]. 2017 Nov [cited 2018 Jul 31];62(S1):S85-94. Available from: http://doi.wiley.com/10.1002/Ino.10471

75. Lau YL. Temperature effect on settling velocity and deposition of cohesive sediments. J Hydraul Eng [Internet]. 1994 Jan [cited 2018 Jul 31];32(1):41-51. Available from: 
http://www.tandfonline.com/doi/abs/10.1080/00221689409498788

76. Butler DR. Zoogeomorphology: Animals as Geomorphic Agents [Internet]. New York: Cambridge University Press; 1995 [cited 2018 Aug 1]. Available from: http://doi.wiley.com/10.2307/2265638

77. Jones CG, Lawton JH, Shachak M. Organisms as Ecosystem Engineers. Oikos [Internet]. 1994;69:373-86. Available from: http://www.jstor.org/stable/3545850?origin=JSTOR-pdf

78. Wright JP, Jones CG. The Concept of Organisms as Ecosystem Engineers Ten Years On: Progress, Limitations, and Challenges. AIBS Bull [Internet]. 2006 Mar 1 [cited 2018 Aug 1];56(3):203-9. Available from: https://academic.oup.com/bioscience/article/56/3/203-209/333061

79. Pakeman J. Multivariate identification of plant functional response and effect traits in an agricultural landscape. Ecology [Internet]. 2011 [cited 2018 Aug 1];92(6):1353-65. Available from: https://esajournals.onlinelibrary.wiley.com/doi/abs/10.1890/10-1728.1

80. Watnick P, Kolter R. Biofilm, city of microbes. J Bacteriol [Internet]. 2000 May 15 [cited 2018 Jul 31];182(10):2675-9. Available from: http://www.ncbi.nlm.nih.gov/pubmed/10781532

81. Nikolaev YA, Plakunov VK. Biofilm - "City of microbes" or an analogue of multicellular organisms? Microbiology [Internet]. 2007 Apr [cited 2018 Jul 31];76(2):125-38. Available from: http://link.springer.com/10.1134/S0026261707020014

82. Lock M. Attached microbial communities in rivers. Aquat Microbiol An Ecol Approach [Internet]. 1993 [cited 2018 Aug 1];113-138. Available from: https://ci.nii.ac.jp/naid/10009490929/

83. Madsen EL. Microorganisms and their roles in fundamental biogeochemical cycles. Curr Opin Biotechnol [Internet]. 2011 Jun 1 [cited $2018 \mathrm{Jul}$ 31];22(3):456-64. Available from: https://www.sciencedirect.com/science/article/pii/S095816691100022X

84. Aspray KL, Holden J, Ledger ME, Mainstone CP, Brown LE. Organic sediment pulses impact rivers across multiple levels of ecological organization. Ecohydrology [Internet]. 2017 Sep 1 [cited 2018 Jul 31];10(6):e1855. Available from: http://doi.wiley.com/10.1002/eco.1855

85. Cheng W, Fang H, Lai H, Huang L, Dey S. Effects of biofilm on turbulence characteristics and the transport of fine sediment. J Soils Sediments [Internet]. 2017 Nov 10 [cited 2018 Jul 31];1-15. Available from: http://link.springer.com/10.1007/s11368-017-1859-1

86. Fang $\mathrm{H}$, Chen $\mathrm{Y}$, Huang $\mathrm{L}, \mathrm{He} \mathrm{G}$. Analysis of biofilm bacterial communities under different shear stresses using size-fractionated sediment. Sci Rep [Internet]. 2017 Dec 2 [cited 2018 Jul 31];7(1):1299. Available from: http://www.nature.com/articles/s41598-017-01446-4

87. Gainswin BE, House WA, Leadbeater BSC, Armitage PD, Patten J. The effects of sediment size fraction and associated algal biofilms on the kinetics of phosphorus release. Sci Total Environ [Internet]. 2006 May 1 [cited $2018 \mathrm{Jul}$ 31];360(1-3):142-57. Available from: https://www.sciencedirect.com/science/article/pii/S0048969705005735

88. Garwood JC, Hill PS, Law BA. Biofilms and Size Sorting of Fine Sediment During Erosion in Intertidal Sands. Estuaries and Coasts [Internet]. 2013 Sep 17 [cited 2018 Jul 31];36(5):1024-36. Available from: http://link.springer.com/10.1007/s12237-013-9618-z 
89. Lu H, Wan J, Li J, Shao H, Wu Y. Periphytic biofilm: A buffer for phosphorus precipitation and release between sediments and water. Chemosphere [Internet]. 2016 Feb 1 [cited 2018 Jul 31];144:2058-64. Available from:

https://www.sciencedirect.com/science/article/pii/S0045653515303246

90. Horton AA, Walton A, Spurgeon DJ, Lahive E, Svendsen C. Microplastics in freshwater and terrestrial environments: Evaluating the current understanding to identify the knowledge gaps and future research priorities. Sci Total Environ [Internet]. 2017 May 15 [cited 2018 Jul 31];586:127-41. Available from:

https://www.sciencedirect.com/science/article/pii/S0048969717302073

91. Rummel CD, Jahnke A, Gorokhova E, Kühnel D, Schmitt-Jansen M. Impacts of biofilm formation on the fate and potential effects of microplastic in the aquatic environment. Environ Sci Technol Lett [Internet]. $2017 \mathrm{Jul} 11$ [cited $2018 \mathrm{Jul}$ 31];4(7):258-67. Available from: http://pubs.acs.org/doi/10.1021/acs.estlett.7b00164

92. Wingender J, Neu TR, Flemming H-C. What are Bacterial Extracellular Polymeric Substances? In: Microbial Extracellular Polymeric Substances [Internet]. Berlin, Heidelberg: Springer Berlin Heidelberg; 1999 [cited 2018 Jul 31]. p. 1-19. Available from: http://link.springer.com/10.1007/978-3-642-60147-7_1

93. Flemming HC, Neu TR, Wozniak DJ. The EPS matrix: The "House of Biofilm Cells." J Bacteriol [Internet]. 2007 Nov 15 [cited 2018 Jul 31];189(22):7945-7. Available from:

http://www.ncbi.nlm.nih.gov/pubmed/17675377

94. Lai H, Fang H, Huang L, He G, Reible D. A review on sediment bioflocculation: Dynamics, influencing factors and modeling. Sci Total Environ [Internet]. 2018 [cited 2018 Aug 1];642:1184200. Available from: https://www.sciencedirect.com/science/article/pii/S0048969718321776

95. Valentine K, Mariotti G, Fagherazzi S. Repeated erosion of cohesive sediments with biofilms. Adv Geosci [Internet]. 2014 Apr 1 [cited 2018 Jul 31];39:9-14. Available from: https://www.advgeosci.net/39/9/2014/

96. Tolhursf TJ, Gust G, Paterson DM. The influence of an extracellular polymeric substance (EPS) on cohesive sediment stability. Proc Mar Sci [Internet]. 2002 Jan 1 [cited 2018 Jul 31];5(C):409-25. Available from: https://www.sciencedirect.com/science/article/pii/S1568269202800304

97. Gerbersdorf SU, Wieprecht S. Biostabilization of cohesive sediments: Revisiting the role of abiotic conditions, physiology and diversity of microbes, polymeric secretion, and biofilm architecture. Geobiology [Internet]. 2015 Jan 1 [cited 2018 Jul 31];13(1):68-97. Available from: http://doi.wiley.com/10.1111/gbi.12115

98. Lee BJ, Hur J, Toorman EA. Seasonal Variation in Flocculation Potential of River Water: Roles of the Organic Matter Pool. Water (Switzerland) [Internet]. 2017 May 8 [cited 2018 Jul 31];9(5):335. Available from: http://www.mdpi.com/2073-4441/9/5/335

99. Passy SI, Larson CA. Succession in Stream Biofilms is an Environmentally Driven Gradient of Stress Tolerance. Microb Ecol [Internet]. 2011 Aug 27 [cited 2018 Jul 31];62(2):414-24. Available from: http://link.springer.com/10.1007/s00248-011-9879-7

100. Dodds WK, Smith VH. Nitrogen, phosphorus, and eutrophication in streams. Inl Waters [Internet]. 
2016 Apr 1 [cited $2018 \mathrm{Jul} 31$ ];6(2):155-64. Available from: http://www.tandfonline.com/doi/full/10.5268/IW-6.2.909

101. Olapade OA, Leff LG. Seasonal response of stream biofilm communities to dissolved organic matter and nutrient enrichments. Appl Environ Microbiol [Internet]. 2005 May 1 [cited 2018 Jul 31];71(5):2278-87. Available from: http://www.ncbi.nlm.nih.gov/pubmed/15870312

102. Besemer K, Singer G, Limberger R, Chlup AK, Hochedlinger G, Hödl I, et al. Biophysical controls on community succession in stream biofilms. Appl Environ Microbiol [Internet]. 2007 Aug 1 [cited 2018 Jul 31];73(15):4966-74. Available from: http://www.ncbi.nlm.nih.gov/pubmed/17557861

103. Prieto DM, Devesa-Rey R, Rubinos DA, Díaz-Fierros F, Barral MT. Biofilm Formation on River Sediments Under Different Light Intensities and Nutrient Inputs: A Flume Mesocosm Study. Environ Eng Sci [Internet]. 2016 Apr 8 [cited 2018 Jul 31];33(4):250-60. Available from: http://online.liebertpub.com/doi/10.1089/ees.2015.0427

104. Fang H, Cheng W, Fazeli M, Dey S. Bedforms and Flow Resistance of Cohesive Beds with and without Biofilm Coating. J Hydraul Eng [Internet]. 2017 Aug [cited 2018 Jul 31];143(8):06017010. Available from: http://ascelibrary.org/doi/10.1061/\%28ASCE\%29HY.1943-7900.0001313

105. Fang H, Fazeli $M$, Cheng W, Dey S. Transport of biofilm-coated sediment particles. J Hydraul Res [Internet]. 2016 Nov 23 [cited 2018 Jul 31];54(6):631-45. Available from: https://www.tandfonline.com/doi/full/10.1080/00221686.2016.1212938

106. Nguyen TH, Tang FHM, Maggi F. Micro food web networks on suspended sediment. Sci Total Environ [Internet]. 2018 Dec 1 [cited 2018 Jul 31];643:1387-99. Available from: https://www.sciencedirect.com/science/article/pii/S0048969718323143

107. Shelford VE. Some Lower Mississippi Valley Flood Plain Biotic Communities: Their age and Elevation. Ecology [Internet]. 1954 Apr [cited 2018 Aug 2];35(2):126. Available from: http://www.jstor.org/stable/1931109?origin=crossref

108. Hupp CR. Vegetation Pattern on Channel Features in the Passage Creek Gorge, Virginia. Castanea [Internet]. 1983 [cited 2018 Aug 2];48(2):62-72. Available from: http://www.jstor.org/stable/4033067

109. Hupp CR. Upstream variation in bottomland vegetation patterns, northwestern Virginia. Bull Torrey Bot Club [Internet]. 1986 [cited 2018 Aug 2];113(4):421-30. Available from: https://www.jstor.org/stable/2996435

110. Corenblit D, Tabacchi E, Steiger J, Gurnell AM. Reciprocal interactions and adjustments between fluvial landforms and vegetation dynamics in river corridors: A review of complementary approaches. Earth-Science Rev [Internet]. 2007 Sep 1 [cited 2018 Jul 31];84(1-2):56-86. Available from: https://www.sciencedirect.com/science/article/pii/S0012825207000682

111. Corenblit D, Steiger J, Gurnell AM, Naiman RJ. Plants intertwine fluvial landform dynamics with ecological succession and natural selection: A niche construction perspective for riparian systems. Glob Ecol Biogeogr [Internet]. 2009 Jul 1 [cited 2018 Jul 31];18(4):507-20. Available from: http://doi.wiley.com/10.1111/j.1466-8238.2009.00461.x

112. Gurnell A. Plants as river system engineers. Earth Surf Process Landforms [Internet]. 2014 Jan 1 
[cited $2018 \mathrm{Jul} 31] ; 39: 4-25$. Available from: https://doi.org/10.1002/esp.3397

113. Asaeda T, Rajapakse L, Kanoh M. Fine sediment retention as affected by annual shoot collapse: Sparganium erectum as an ecosystem engineer in a lowland stream. River Res Appl [Internet]. 2010 Nov 1 [cited 2018 Jul 31];26(9):1153-69. Available from: http://doi.wiley.com/10.1002/rra.1322

114. Liffen T, Gurnell AM, O'Hare MT, Pollen-Bankhead N, Simon A. Biomechanical properties of the emergent aquatic macrophyte Sparganium erectum: Implications for fine sediment retention in low energy rivers. Ecol Eng [Internet]. 2011 Nov 1 [cited 2018 Jul 31];37(11):1925-31. Available from: https://www.sciencedirect.com/science/article/pii/S0925857411002023

115. Cotton JA, Wharton G, Bass JAB, Heppell CM, Wotton RS. The effects of seasonal changes to instream vegetation cover on patterns of flow and accumulation of sediment. Geomorphology [Internet]. $2006 \mathrm{Jul} 30$ [cited $2018 \mathrm{Jul} 31$ ]; 77(3-4):320-34. Available from: https://www.sciencedirect.com/science/article/pii/S0169555X06000201

116. Abbe TB, Montgomery DR. Patterns and processes of wood debris accumulation in the Queets river basin, Washington. Geomorphology [Internet]. 2003 Mar 20 [cited 2018 Jul 31];51(1-3):81107. Available from: https://www.sciencedirect.com/science/article/pii/S0169555X02003264

117. Nachtergaele J, Poesen J, Vandekerckhove L, Oostwoud Wijdenes D, Roxo M. Riparian vegetation and island formation along the gravel-bed Fiume Tagliamento, Italy. Earth Surf Process Landforms [Internet]. 2001 Jan 1 [cited 2018 Jul 31];26(1):31-62. Available from: http://doi.wiley.com/10.1002/1096-9837\%28200101\%2926\%3A1\%3C31\%3A\%3AAIDESP155\%3E3.0.CO\%3B2-Y

118. Gurnell A, Tockner K, Edwards P, Petts G. Effects of deposited wood on biocomplexity of river corridors. Front Ecol Environ [Internet]. 2005 Sep 1 [cited 2018 Jul 31];3(7):377-82. Available from: https://esajournals.onlinelibrary.wiley.com/doi/abs/10.1890/15409295(2005)003\%5B0377:EODWOB\%5D2.0.CO\%3B2

119. Rood SB, Goater LA, Gill KM, Braatne JH. Sand and sandbar willow: A feedback loop amplifies environmental sensitivity at the riparian interface. Oecologia [Internet]. 2011 Jan 29 [cited 2018 Jul 31];165(1):31-40. Available from: http://link.springer.com/10.1007/s00442-010-1758-2

120. Pettit NE, Latterell JJ, Naiman RJ. Formation, distribution and ecological consequences of floodrelated wood debris piles in a bedrock confined river in semi-arid South Africa. River Res Appl [Internet]. 2006 Dec 1 [cited 2018 Jul 31];22(10):1097-110. Available from: http://doi.wiley.com/10.1002/rra.959

121. Sand-Jensen K. Influence of submerged macrophytes on sediment composition and near-bed flow in lowland streams. Freshw Biol [Internet]. 1998 Jun 1 [cited 2018 Jul 31];39(4):663-79. Available from: http://doi.wiley.com/10.1046/j.1365-2427.1998.00316.x

122. Gurnell AM, Morrissey IP, Boitsidis AJ, Bark T, Clifford NJ, Petts GE, et al. Initial adjustments within a new river channel: Interactions between fluvial processes, colonizing vegetation, and bank profile development. Environ Manage [Internet]. 2006 Oct 23 [cited 2018 Aug 2];38(4):58096. Available from: http://link.springer.com/10.1007/s00267-005-0190-6

123. Luhar M, Rominger J, Nepf H. Interaction between flow, transport and vegetation spatial 

Available from: http://link.springer.com/10.1007/s10652-008-9080-9

124. Gurnell AM, Bertoldi W, Corenblit D. Changing river channels: The roles of hydrological processes, plants and pioneer fluvial landforms in humid temperate, mixed load, gravel bed rivers. Earth-Science Rev [Internet]. 2012 Feb 1 [cited 2018 Jul 31];111(1-2):129-41. Available from: https://www.sciencedirect.com/science/article/pii/S0012825211001693

125. Schoelynck J, De Groote T, Bal K, Vandenbruwaene W, Meire P, Temmerman S. Self-organised patchiness and scale-dependent bio-geomorphic feedbacks in aquatic river vegetation. Ecography (Cop) [Internet]. 2012 Aug 1 [cited 2018 Jul 31];35(8):760-8. Available from: http://doi.wiley.com/10.1111/j.1600-0587.2011.07177.x

126. Liffen T, Gurnell AM, O'Hare MT, Pollen-Bankhead N, Simon A. Associations between the morphology and biomechanical properties of Sparganium erectum: Implications for survival and ecosystem engineering. Aquat Bot [Internet]. 2013 Feb 1 [cited 2018 Jul 31];105:18-24. Available from: https://www.sciencedirect.com/science/article/pii/S0304377012001829

127. Ghisalberti M, Nepf H. Shallow flows over a permeable medium: The hydrodynamics of submerged aquatic canopies. Transp Porous Media [Internet]. 2009 Jun 10 [cited 2018 Jul 31];78(3 SPEC. ISS.):385-402. Available from: http://link.springer.com/10.1007/s11242-0089305-x

128. Gurnell AM, O'Hare JM, O'Hare MT, Dunbar MJ, Scarlett PM. An exploration of associations between assemblages of aquatic plant morphotypes and channel geomorphological properties within British rivers. Geomorphology [Internet]. 2010 [cited 2018 Oct 22];116(1-2):135-44. Available from: https://www.sciencedirect.com/science/article/pii/S0169555X09004504

129. Gurnell AM, O'Hare MT, O'Hare JM, Scarlett P, Liffen TMR. The geomorphological context and impact of the linear emergent macrophyte, Sparganium erectum L.: A statistical analysis of observations from British rivers. Earth Surf Process Landforms [Internet]. 2013 [cited 2018 Oct 22];38(15):1869-80. Available from: https://onlinelibrary.wiley.com/doi/abs/10.1002/esp.3473

130. Collins BD, Montgomery DR, Fetherston KL, Abbe TB. The floodplain large-wood cycle hypothesis: A mechanism for the physical and biotic structuring of temperate forested alluvial valleys in the North Pacific coastal ecoregion. Geomorphology [Internet]. 2012 Feb 15 [cited 2018 Jul 31];139140:460-70. Available from: https://www.sciencedirect.com/science/article/pii/S0169555X11006088

131. Karrenberg S, Edwards PJ, Kollmann J. The life history of Salicaceae living in the active zone of floodplains. Freshw Biol [Internet]. 2002 Apr 1 [cited 2018 Jul 31];47(4):733-48. Available from: http://doi.wiley.com/10.1046/j.1365-2427.2002.00894.x

132. Holloway J V., Rillig MC, Gurnell AM. Underground riparian wood: Reconstructing the processes influencing buried stem and coarse root structures of Black Poplar (Populus nigra L.). Geomorphology [Internet]. 2017 Feb 15 [cited 2018 Jul 31];279:199-208. Available from: https://www.sciencedirect.com/science/article/pii/S0169555X16306869

133. Pasquale N, Perona P, Francis R, Burlando P. Effects of streamflow variability on the vertical root density distribution of willow cutting experiments. Ecol Eng [Internet]. 2012 Mar 1 [cited 2018 Jul 
31];40:167-72. Available from:

https://www.sciencedirect.com/science/article/pii/S0925857411003697

134. Tron S, Perona P, Gorla L, Schwarz M, Laio F, Ridolfi L. The signature of randomness in riparian plant root distributions. Geophys Res Lett [Internet]. 2015 Sep 16 [cited 2018 Jul 31];42(17):7098-106. Available from: http://doi.wiley.com/10.1002/2015GL064857

135. Gurnell AM, Corenblit D, García de Jalón D, González del Tánago M, Grabowski RC, O’Hare MT, et al. A Conceptual Model of Vegetation-hydrogeomorphology Interactions Within River Corridors. River Res Appl [Internet]. 2016 Feb 1 [cited 2018 Jul 31];32(2):142-63. Available from: http://doi.wiley.com/10.1002/rra.2928

136. Zen S, Gurnell AM, Zolezzi G, Surian N. Exploring the role of trees in the evolution of meander bends: The Tagliamento River, Italy. Water Resour Res [Internet]. 2017 Jul 1 [cited 2018 Jul 31];53(7):5943-62. Available from: http://doi.wiley.com/10.1002/2017WR020561

137. Greenwood P, Kuhn NJ. Does the invasive plant, Impatiens glandulifera, promote soil erosion along the riparian zone? An investigation on a small watercourse in northwest Switzerland. J Soils Sediments [Internet]. 2014 Mar 20 [cited 2018 Jul 31];14(3):637-50. Available from: http://link.springer.com/10.1007/s11368-013-0825-9

138. Greenwood P, Baumann P, Pulley S, Kuhn NJ. The invasive alien plant, Impatiens glandulifera (Himalayan Balsam), and increased soil erosion: causation or association? Case studies from a river system in Switzerland and the UK. J Soils Sediments [Internet]. 2018 Jun 4 [cited 2018 Jul 31];1-15. Available from: http://link.springer.com/10.1007/s11368-018-2041-0

139. Albertson LK, Allen DC, Trexler JC. Meta-analysis: Abundance, behavior, and hydraulic energy shape biotic effects on sediment transport in streams. Ecology [Internet]. 2015 May [cited 2018 Aug 2];96(5):1329-39. Available from: http://doi.wiley.com/10.1890/13-2138.1

140. Statzner B. Geomorphological implications of engineering bed sediments by lotic animals. Geomorphology [Internet]. 2012 Jul 1 [cited 2018 Aug 1];157-158:49-65. Available from: https://www.sciencedirect.com/science/article/pii/S0169555X11003060

141. Albertson LK, Daniels MD. Effects of invasive crayfish on fine sediment accumulation, gravel movement, and macroinvertebrate communities. Freshw Sci [Internet]. 2016 Jun 12 [cited 2018 Aug 1];35(2):644-53. Available from: http://www.journals.uchicago.edu/doi/10.1086/685860

142. Rice SP, Johnson MF, Extence C, Reeds J, Longstaff H. Diel patterns of suspended sediment flux and the zoogeomorphic agency of invasive crayfish. Cuad Investig Geográfica [Internet]. 2014 Mar 6 [cited 2018 Aug 1];40(1):7. Available from: https://publicaciones.unirioja.es/ojs/index.php/cig/article/view/2508

143. Holdich DM, James J, Jackson C, Peay S. The North American signal crayfish, with particular reference to its success as an invasive species in Great Britain. Ethol Ecol Evol [Internet]. $2014 \mathrm{Jul}$ 3 [cited 2018 Aug 1];26(2-3):232-62. Available from: http://www.tandfonline.com/doi/abs/10.1080/03949370.2014.903380

144. Pringle CM, Blake GA, Covich AP, Buzby KM, Finley A. Effects of omnivorous shrimp in a montane tropical stream: sediment removal, disturbance of sessile invertebrates and enhancement of understory algal biomass. Oecologia [Internet]. 1993 Feb [cited 2018 Aug 2];93(1):1-11. Available 
from: http://link.springer.com/10.1007/BF00321183

145. Visoni SBC, Moulton TP. Effects of shrimp on periphyton and sediments in Atlantic forest streams: an exclusion experiment. Acta Limnol Bras. 2003;15(1):19-26.

146. Statzner B, Fuchs U, Higler LWG. Sand erosion by mobile predaceous stream insects: Implications for ecology and hydrology. Water Resour Res [Internet]. 1996 Jul 1 [cited 2018 Aug 1];32(7):2279-87. Available from: http://doi.wiley.com/10.1029/96WR00977

147. Soluk DA, Craig DA. Digging with a vortex: Flow manipulation facilitates prey capture by a predatory stream mayfly. Limnol Oceanogr [Internet]. 1990 Jul 1 [cited 2018 Aug 1];35(5):12016. Available from: http://doi.wiley.com/10.4319/lo.1990.35.5.1201

148. Mermillod-Blondin F, Gérino M, Degrange V. Functional Diversity among 3 Detritivorous Hyporheic Invertebrates: An Experimental Study in Microcosms. J North Am Benthol Soc [Internet]. 2002 Mar 21 [cited 2018 Aug 1];21(1):132-49. Available from: http://www.journals.uchicago.edu/doi/10.2307/1468305

149. Mermillod-Blondin F, Gaudet JP, Gérino M, Desrosiers G, Creuzé des Châtelliers M. Influence of macroinvertebrates on physico-chemical and microbial processes in hyporheic sediments. Hydrol Process [Internet]. 2003 Mar 1 [cited 2018 Aug 1];17(4):779-94. Available from: http://doi.wiley.com/10.1002/hyp.1165

150. Mermillod-Blondin F, Gaudet JP, Gerino M, Desrosiers G, Jose J, Creuzé Des Châtelliers M. Relative influence of bioturbation and predation on organic matter processing in river sediments: A microcosm experiment. Freshw Biol [Internet]. 2004 Jul 1 [cited 2018 Aug 1];49(7):895-912. Available from: http://doi.wiley.com/10.1111/j.1365-2427.2004.01233.x

151. Mermillod-Blondin F, Rosenberg R. Ecosystem engineering: The impact of bioturbation on biogeochemical processes in marine and freshwater benthic habitats. Aquat Sci [Internet]. 2006 Dec 4 [cited 2018 Aug 1];68(4):434-42. Available from: http://link.springer.com/10.1007/s00027006-0858-x

152. Nogaro G, Mermillod-Blondin F, François-Carcaillet F, Gaudet JP, Lafont M, Gibert J. Invertebrate bioturbation can reduce the clogging of sediment: An experimental study using infiltration sediment columns. Freshw Biol [Internet]. 2006 Aug 1 [cited 2018 Aug 1];51(8):1458-73. Available from: http://doi.wiley.com/10.1111/j.1365-2427.2006.01577.x

153. Nogaro G, Mermillod-Blondin F, Valett MH, François-Carcaillet F, Gaudet JP, Lafont M, et al. Ecosystem engineering at the sediment-water interface: Bioturbation and consumer-substrate interaction. Oecologia [Internet]. 2009 Aug 22 [cited 2018 Aug 1];161(1):125-38. Available from: http://link.springer.com/10.1007/s00442-009-1365-2

154. Zimmerman GF, de Szalay FA. Influence of unionid mussels (Mollusca: Unionidae) on sediment stability: an artificial stream study. Fundam Appl Limnol / Arch für Hydrobiol [Internet]. 2007 [cited 2018 Aug 2];168(4):299-306. Available from: http://openurl.ingenta.com/content/xref?genre=article\&issn=18639135\&volume $=168 \&$ issue $=4 \&$ spage $=299$

155. Allen JRL. Experiments on the settling, overturning and entrainment of bivalve shells and related models. Sedimentology [Internet]. 1984 Apr 1 [cited 2018 Aug 2];31(2):227-50. Available from: 
http://doi.wiley.com/10.1111/j.1365-3091.1984.tb01961.x

156. Nogaro G, Mermillod-Blondin F, Montuelle B, Boisson JC, Gibert J. Chironomid larvae stimulate biogeochemical and microbial processes in a riverbed covered with fine sediment. Aquat Sci [Internet]. 2008 May 5 [cited 2018 Aug 2];70(2):156-68. Available from: http://link.springer.com/10.1007/s00027-007-7032-y

157. Statzner B, Arens MF, Champagne JY, Morel R, Herouin E. Silk-producing stream insects and gravel erosion: Significant biological effects on critical shear stress. Water Resour Res [Internet]. 1999 Nov 1 [cited 2018 Aug 1];35(11):3495-506. Available from: http://doi.wiley.com/10.1029/1999WR900196

158. Takao A, Negishi JN, Nunokawa M, Gomi T, Nakahara O. Potential influences of a net-spinning caddisfly (Trichoptera:Stenopsyche marmorata) on stream substratum stability in heterogeneous field environments. Benthol Soc [Internet]. 2006 [cited 2018 Aug 2];25(3):545-55. Available from: https://www.journals.uchicago.edu/doi/abs/10.1899/08873593(2006)25\%5B545\%3APIOANC\%5D2.0.CO\%3B2

159. Nunokawa M, Gomi T, Negishi JN, Nakahara O. A new method to measure substrate coherent strength of Stenopsyche marmorata. Landsc Ecol Eng [Internet]. 2008 Nov 19 [cited 2018 Aug 2];4(2):125-31. Available from: http://link.springer.com/10.1007/s11355-008-0044-5

160. Cardinale BJ, Gelmann ER, Palmer MA. Net spinning caddisflies as stream ecosystem engineers: The influence of Hydropsyche on benthic substrate stability. Funct Ecol [Internet]. 2004 Jun 1 [cited 2018 Aug 1];18(3):381-7. Available from: http://doi.wiley.com/10.1111/j.02698463.2004.00865.x

161. Albertson LK, Cardinale BJ, Sklar LS. Non-additive increases in sediment stability are generated by macroinvertebrate species interactions in laboratory streams. Fukami T, editor. PLoS One [Internet]. 2014 Aug 7 [cited 2018 Aug 2];9(8):e103417. Available from: http://dx.plos.org/10.1371/journal.pone.0103417

162. Johnson MF, Reid I, Rice SP, Wood PJ. Stabilization of fine gravels by net-spinning caddisfly larvae. Earth Surf Process Landforms [Internet]. 2009 Mar 15 [cited 2018 Aug 1];34(3):413-23. Available from: http://doi.wiley.com/10.1002/esp.1750

163. Statzner B, Mérigoux S, Leichtfried M. Mineral grains in caddisfly pupal cases and streambed sediments: Resource use and its limitation through conflicting resource requirements. Limnol Oceanogr [Internet]. 2005 Mar [cited 2018 Aug 2];50(2):713-21. Available from: http://doi.wiley.com/10.4319/lo.2005.50.2.0713

164. Statzner B. Mineral grains in caddisfly pupal cases and streambed sediments- assessing resource use and its limitations across various river types. cambridge.org [Internet]. [cited 2018 Aug 2]; Available from: https://www.cambridge.org/core/journals/annales-de-limnologie-internationaljournal-of-limnology/article/mineral-grains-in-caddisfly-pupal-cases-and-streambed-sedimentsassessing-resource-use-and-its-limitation-across-various-river-types/EC6C90B23F2EA52DF

165. Wharton G, Cotton JA, Wotton RS, Bass JAB, Heppell CM, Trimmer M, et al. Macrophytes and suspension-feeding invertebrates modify flows and fine sediments in the Frome and Piddle catchments, Dorset (UK). J Hydrol [Internet]. 2006 Oct 30 [cited 2018 Aug 1];330(1-2):171-84. 
Available from: https://www.sciencedirect.com/science/article/pii/S0022169406001995

166. Wotton RS, Warren LL. Impacts of suspension feeders on the modification and transport of stream seston. Fundam Appl Limnol. 2007 Jul 1;169(3):231-6.

167. Balian E V., Segers H, Martens K, Lévéque C. The Freshwater Animal Diversity Assessment: an overview of the results. In: Freshwater Animal Diversity Assessment [Internet]. Dordrecht: Springer Netherlands; [cited 2018 Aug 2]. p. 627-37. Available from: http://link.springer.com/10.1007/978-1-4020-8259-7_61

168. Strayer DL, Dudgeon D. Freshwater biodiversity conservation: recent progress and future challenges. J North Am Benthol Soc [Internet]. 2010 Mar [cited 2018 Aug 2];29(1):344-58. Available from: http://www.journals.uchicago.edu/doi/10.1899/08-171.1

169. WWF (World Wide Fund for Nature). Living Planet Report 2016. Risk and resilience in a new era [Internet]. 2016 [cited 2018 Aug 2]. Available from: http://awsassets.panda.org/downloads/Ipr_living_planet_report_2016.pdf

170. Poff NL, Olden JD, Strayer DL. Climate Change and Freshwater Fauna Extinction Risk. In: Saving a Million Species [Internet]. Washington, DC: Island Press/Center for Resource Economics; 2012 [cited 2018 Aug 2]. p. 309-36. Available from: http://www.springerlink.com/index/10.5822/9781-61091-182-5_17

171. Strayer DL. Challenges for freshwater invertebrate conservation. J North Am Benthol Soc [Internet]. 2006 [cited 2018 Aug 2];25(2):271-87. Available from: http://www.journals.uchicago.edu/doi/10.1899/0887-3593(2006)25[271:CFFIC]2.0.CO;2

172. Burner CJ. Characteristics of spawning nests of Columbia River salmon [Internet]. Vol. 52, U.S. Fish and Wildlife Service Fishery Bulletin. 1951 [cited 2018 Aug 2]. 94-110 p. Available from: https://www.nwfsc.noaa.gov/assets/2/9171_07142017_163818_Burner.1951-Fish-Bull-61-521.pdf

173. DeVries P. Salmonid influences on rivers: A geomorphic fish tail. Geomorphology [Internet]. 2012 [cited 2018 Aug 2];157-158:66-74. Available from: https://www.sciencedirect.com/science/article/pii/S0169555X11003011

174. Rice S, Stoffel M, Turowski JM, Wolf A. Disturbance regimes at the interface of geomorphology and ecology. Earth Surf Process Landforms [Internet]. 2012 Dec 1 [cited 2018 Aug 2];37(15):1678-82. Available from: http://doi.wiley.com/10.1002/esp.3326

175. Rennie CD, Millar RG. Spatial variability of stream bed scour and fill: A comparison of scour depth in chum salmon (Oncorhynchus keta) redds and adjacent bed. Can J Fish Aquat Sci [Internet]. 2000 May [cited 2018 Aug 2];57(5):928-38. Available from: http://narwhal.cisti.nrc.ca/cgibin/rp/servlets/ppv/RPViewDoc?_handler_=HandlelnitialGet\&issn=0706652X\&volume=57\&issue $=5 \&$ startPage $=928 \% 5 \mathrm{Cnhttp}: / /$ www.nrc.ca/cgi-bin/cisti/journals/rp/rp2*desc*e?cjfas

176. Buxton TH, Buffington JM, Yager EM, Hassan MA, Fremier AK. The relative stability of salmon redds and unspawned streambeds. Water Resour Res [Internet]. 2015 Aug 1 [cited 2018 Aug 2];51(8):6074-92. Available from: http://doi.wiley.com/10.1002/2015WR016908

177. Montgomery DR, Buffington JM, Peterson NP, Schuett-Hames D, Quinn TP. Stream-bed scour, 
egg burial depths, and the influence of salmonid spawning on bed surface mobility and embryo survival. Can J Fish Aquat Sci [Internet]. 1996 May [cited 2018 Aug 2];53(5):1061-70. Available from: http://www.nrcresearchpress.com/doi/abs/10.1139/f96-028

178. Hassan MA, Gottesfeld AS, Montgomery DR, Tunnicliffe JF, Clarke GKC, Wynn G, et al. Salmondriven bed load transport and bed morphology in mountain streams. Geophys Res Lett [Internet]. 2008 Feb 22 [cited 2018 Aug 2];35(4):L04405. Available from: http://doi.wiley.com/10.1029/2007GL032997

179. Gottesfeld AS, Hassan MA, Tunnicliffe JF, Poirier RW. Sediment dispersion in salmon spawning streams: The influence of floods and salmon redd construction. J Am Water Resour Assoc [Internet]. 2004 Aug 1 [cited 2018 Aug 2];40(4):1071-86. Available from: http://doi.wiley.com/10.1111/j.1752-1688.2004.tb01068.x

180. Fremier AK, Yanites BJ, Yager EM. Sex that moves mountains: The influence of spawning fish on river profiles over geologic timescales. Geomorphology [Internet]. 2017 [cited 2018 Aug 2]; Available from: https://www.sciencedirect.com/science/article/pii/S0169555X17302155

181. Wright RM. Aspects of the ecology of bream, Abramis brama (L.), in a gravel pit lake and the effects of reducing the population density. J Fish Biol [Internet]. 1990 Jan 24 [cited 2018 Aug 2];37(4):629-34. Available from: http://doi.wiley.com/10.1111/j.1095-8649.1990.tb05896.x

182. Huser BJ, Bajer PG, Chizinski CJ, Sorensen PW. Effects of common carp (Cyprinus carpio) on sediment mixing depth and mobile phosphorus mass in the active sediment layer of a shallow lake. Hydrobiologia [Internet]. 2016 Jan 12 [cited 2018 Aug 2];763(1):23-33. Available from: http://link.springer.com/10.1007/s10750-015-2356-4

183. Pledger AG, Rice SP, Millett J. Reduced bed material stability and increased bedload transport caused by foraging fish: A flume study with juvenile Barbel (Barbus barbus). Earth Surf Process Landforms [Internet]. 2014 May 15 [cited 2018 Aug 2];39(11):1500-13. Available from: http://doi.wiley.com/10.1002/esp.3592

184. Barton DR, Kelton N, Eedy RI. The effects of carp (Cyprinus carpio L.) on sediment export from a small urban impoundment. J Aquat Ecosyst Stress Recover (Formerly J Aquat Ecosyst Heal [Internet]. 2000 [cited 2018 Aug 2];8(2):155-9. Available from: https://link.springer.com/article/10.1023/A:1011423432727

185. Breukelaar AW, Lammens EHRR, Breteler JGPK, Tátri I. Effects of benthivorous bream (Abramis brama) and carp (Cyprinus carpio) on sediment resuspension and concentrations of nutrients and chlorophyll a. Freshw Biol [Internet]. 1994 Aug [cited 2018 Aug 2];32(1):113-21. Available from: http://doi.wiley.com/10.1111/j.1365-2427.1994.tb00871.x

186. Cahn AR. The Effect of Carp on a Small Lake : the Carp as a Dominant. Ecology [Internet]. 1929 Jul [cited 2018 Aug 2];10(3):271-4. Available from: http://doi.wiley.com/10.2307/1929502

187. Parkos III JJ, Santucci, Jr. VJ, Wahl DH. Effects of adult common carp (Cyprinus carpio) on multiple trophic levels in shallow mesocosms. Can J Fish Aquat Sci [Internet]. 2003 [cited 2018 Aug 2];60(2):182-92. Available from: http://www.nrcresearchpress.com/doi/abs/10.1139/f03-011

188. Pledger AG, Rice SP, Millett J. Bed disturbance via foraging fish increases bedload transport during subsequent high flows and is controlled by fish size and species. Geomorphology 
[Internet]. 2016 [cited 2018 Aug 2];253:83-93. Available from: https://www.sciencedirect.com/science/article/pii/S0169555X15301562

189. Statzner B, Sagnes P, Champagne JY, Viboud S. Contribution of benthic fish to the patch dynamics of gravel and sand transport in streams. Water Resour Res [Internet]. 2003 Nov [cited 2018 Aug 2];39(11). Available from: http://doi.wiley.com/10.1029/2003WR002270

190. Moore JW, Schindler DE, Carter JL, Fox J, Griffiths J, Holtgrieve GW. Biotic control of stream fluxes: spawning salmon drive nutrient and matter export. Ecology [Internet]. 2007;88(5):127891. Available from: https://esajournals.onlinelibrary.wiley.com/doi/abs/10.1890/06-0782

191. Cak AD, Chaloner DT, Lamberti GA. Effects of spawning salmon on dissolved nutrients and epilithon in coupled stream-estuary systems of southeastern Alaska. Aquat Sci [Internet]. 2008;70(2):169-178. Available from: https://link.springer.com/article/10.1007/s00027-008$8090-5$

192. Usseglio-Polatera $\mathrm{P}$, Bournaud M, Richoux $\mathrm{P}$, Tachet $\mathrm{H}$. Biological and ecological traits of benthic freshwater macroinvertebrates: Relationships and definition of groups with similar traits. Freshw Biol [Internet]. 2000 Feb 1 [cited 2018 Aug 1];43(2):175-205. Available from: http://doi.wiley.com/10.1046/j.1365-2427.2000.00535.x

193. Lamouroux N, Dolédec S, Gayraud S. Biological traits of stream macroinvertebrate communities: effects of microhabitat, reach, and basin filters. J North Am Benthol Soc [Internet]. 2004 Sep [cited 2018 Aug 1];23(3):449-66. Available from: http://www.journals.uchicago.edu/doi/10.1899/08873593(2004)023\%3C0449:BTOSMC\%3E2.0.CO;2

194. Altermatt F. Diversity in riverine metacommunities: A network perspective. Aquat Ecol [Internet]. 2013 Sep 14 [cited $2018 \mathrm{Jul} 26$ ];47(3):365-77. Available from: http://link.springer.com/10.1007/s10452-013-9450-3

195. Prunier JG, Dubut V, Loot G, Tudesque L, Blanchet S. The relative contribution of river network structure and anthropogenic stressors to spatial patterns of genetic diversity in two freshwater fishes: A multiple-stressors approach. Freshw Biol [Internet]. 2018 Jan 1 [cited 2018 Aug 1];63(1):6-21. Available from: http://doi.wiley.com/10.1111/fwb.13034

196. Hanski I. Metapopulation dynamics. Nature [Internet]. 1998 Nov 5 [cited 2018 Aug 1];396(6706):41-9. Available from: http://www.nature.com/articles/23876

197. Poff NL. Landscape Filters and Species Traits: Towards Mechanistic Understanding and Prediction in Stream Ecology. J North Am Benthol Soc [Internet]. 1997 Jun [cited 2018 Aug 2];16(2):391409. Available from: http://www.journals.uchicago.edu/doi/10.2307/1468026

198. Leibold MA, Holyoak M, Mouquet N, Amarasekare P, Chase JM, Hoopes MF, et al. The metacommunity concept: A framework for multi-scale community ecology. Ecol Lett [Internet]. 2004 Jun 4 [cited 2018 Aug 1];7(7):601-13. Available from: http://doi.wiley.com/10.1111/j.14610248.2004.00608.x

199. Vannote RL, Minshall GW, Cummins KW, Sedell JR, Cushing CE. The River Continuum Concept. Can J Fish Aquat Sci [Internet]. 1980 Jan [cited 2018 Aug 1];37(1):130-7. Available from: http://www.nrcresearchpress.com/doi/abs/10.1139/f80-017 
200. Junk W, Bayley PB, Sparks RE. The flood pulse concept in river-floodplain-systems. Can Spec Publ Fish Aquat Sci. 1989;106:110-27.

201. Ward J V., Stanford JA. The serial discontinuity concept: Extending the model to floodplain rivers. Regul Rivers Res Manag [Internet]. 1995 Aug [cited 2018 Aug 1];10(2-4):159-68. Available from: http://doi.wiley.com/10.1002/rrr.3450100211

202. Winegardner AK, Jones BK, Ng ISY, Siqueira T, Cottenie K. The terminology of metacommunity ecology. Trends Ecol Evol [Internet]. 2012 May 1 [cited 2018 Aug 1];27(5):253-4. Available from: http://www.ncbi.nlm.nih.gov/pubmed/22325446

203. Gaston KJ. Global patterns in biodiversity. Nature [Internet]. 2000 May 11 [cited 2018 Aug 1];405(6783):220-7. Available from: http://www.nature.com/articles/35012228

204. Brown LE, Khamis K, Wilkes M, Blaen P, Brittain JE, Carrivick JL, et al. Functional diversity and community assembly of river invertebrates show globally consistent responses to decreasing glacier cover. Nat Ecol Evol [Internet]. 2018 Feb 18 [cited 2018 Aug 2];2(2):325-33. Available from: http://www.nature.com/articles/s41559-017-0426-x

205. Radinger J, Essl F, Hölker F, Horký P, Slavík O, Wolter C. The future distribution of river fish: The complex interplay of climate and land use changes, species dispersal and movement barriers. Glob Chang Biol [Internet]. 2017 Nov 1 [cited 2018 Aug 2];23(11):4970-86. Available from: http://doi.wiley.com/10.1111/gcb.13760

206. Karger DN, Cord AF, Kessler M, Kreft H, Kühn I, Pompe S, et al. Delineating probabilistic species pools in ecology and biogeography. Glob Ecol Biogeogr [Internet]. 2016 Apr 1 [cited 2018 Aug 1];25(4):489-501. Available from: http://doi.wiley.com/10.1111/geb.12422

207. Vermaat JE, De Bruyne RJ. Factors limiting the distribution of submerged waterplants in the lowland River Vecht (The Netherlands). Freshw Biol [Internet]. 1993 Aug 1 [cited 2018 Aug 2];30(1):147-57. Available from: http://doi.wiley.com/10.1111/j.1365-2427.1993.tb00795.x

208. LaPerriere JD, Bjerklie DM, Simmons RC, Van Nieuwenhuyse EE, Wagener SM, Reynolds JB. Effects of gold placer mining on interior Alaskan stream ecosystems. Manag water Resour Alaska's Dev proceedingsUniversity Alaska, Inst Water Resour Rep IWR-105, Fairbanks, AK [Internet]. 1983 [cited 2018 Aug 2];12-34. Available from: https://core.ac.uk/download/pdf/130253707.pdf\#page=251

209. Rivier B, Seguier J. Physical and biological effects of gravel extraction in river beds. Habitat Modif Freshw Fish Proc a Symp Eur Inl Fish Advis Comm [Internet]. 1985 [cited 2018 Aug 2];131-45. Available from: http://agris.fao.org/agris-search/search.do?recordID=XF2016073716

210. Van Nieuwenhuyse EE, LaPerriere JD. Effects of Placer Gold Mining on Primary Production in Subarctic Streams of Alaska. JAWRA J Am Water Resour Assoc [Internet]. 1986 Feb [cited 2018 Aug 2];22(1):91-9. Available from: http://doi.wiley.com/10.1111/j.1752-1688.1986.tb01864.x

211. Lloyd DS, Koenings JP, Laperriere JD. Effects of Turbidity in Fresh Waters of Alaska. North Am J Fish Manag [Internet]. 1987 Jan [cited 2018 Aug 2];7(1):18-33. Available from: http://www.tandfonline.com/doi/abs/10.1577/15488659\%281987\%297\%3C18\%3AEOTIFW\%3E2.0.CO\%3B2 
212. Harper MA. Migration rhythm of the benthic diatom pinnularia virjdis on pond silt (Note). New Zeal J Mar Freshw Res [Internet]. 1976 Jun 30 [cited 2018 Aug 2];10(2):381-4. Available from: http://www.tandfonline.com/doi/abs/10.1080/00288330.1976.9515622

213. Hay SI, Maitland TC, Paterson DM. The speed of diatom migration through natural and artificial substrata. Diatom Res [Internet]. 1993 Nov [cited 2018 Aug 2];8(2):371-84. Available from: http://www.tandfonline.com/doi/abs/10.1080/0269249X.1993.9705268

214. Yamada H, Nakamura F. Effect of fine sediment deposition and channel works on periphyton biomass in the Makomanai River, northern Japan. River Res Appl [Internet]. 2002 Sep [cited 2018 Aug 2];18(5):481-93. Available from: http://doi.wiley.com/10.1002/rra.688

215. Dickman MD, Peart MR, Wai-Shu Yim W. Benthic Diatoms as Indicators of Stream Sediment Concentrationin Hong Kong. Int Rev Hydrobiol [Internet]. 2005 Aug [cited 2018 Aug 2];90(4):41221. Available from: http://doi.wiley.com/10.1002/iroh.200410806

216. Izagirre O, Serra A, Guasch H, Elosegi A. Effects of sediment deposition on periphytic biomass, photosynthetic activity and algal community structure. Sci Total Environ [Internet]. 2009 Oct 15 [cited 2018 Aug 2];407(21):5694-700. Available from: https://www.sciencedirect.com/science/article/pii/S0048969709006299

217. Jones JI, Douthwright TA, Arnold A, Duerdoth CP, Murphy JF, Edwards FK, et al. Diatoms as indicators of fine sediment stress. Ecohydrology [Internet]. 2017 Jul 1 [cited 2018 Aug 2];10(5):e1832. Available from: http://doi.wiley.com/10.1002/eco.1832

218. Biggs BJF, Kilroy C, Lowe RL. Periphyton development in three valley segments of a New Zealand grassland river: test of a habitat matrix conceptual model within a catchment. Arch für Hydrobiol [Internet]. 1998 Oct 20 [cited 2018 Aug 2];143(2):147-77. Available from:

http://www.schweizerbart.de/papers/fal/detail/143/86229/Periphyton_development_in_three_ valley_segments_of?af=crossref

219. Biggs BJF, Smith RA. Taxonomic richness of stream benthic algae: Effects of flood disturbance and nutrients. Limnol Oceanogr [Internet]. 2002 Jul 1 [cited 2018 Aug 2];47(4):1175-86. Available from: http://doi.wiley.com/10.4319/lo.2002.47.4.1175

220. Matthaei CD, Guggelberger C, Hubre H. Local disturbance history affects patchiness of benthic river algae. Freshw Biol [Internet]. 2003 Sep 1 [cited 2018 Aug 2];48(9):1514-26. Available from: http://doi.wiley.com/10.1046/j.1365-2427.2003.01103.x

221. Francoeur SN, Biggs BJF. Short-term effects of elevated velocity and sediment abrasion on benthic algal communities. Hydrobiologia [Internet]. 2006 May [cited 2018 Aug 2];561(1):59-69. Available from: http://link.springer.com/10.1007/s10750-005-1604-4

222. Delgado M, De Jonge VN, Peletier H. Effect of sand movement on the growth of benthic diatoms. J Exp Mar Bio Ecol [Internet]. 1991 Mar 8 [cited 2018 Aug 2];145(2):221-31. Available from: https://www.sciencedirect.com/science/article/pii/002209819190177X

223. Jewson DH, Lowry SF, Bowen R. Co-existence and survival of diatoms on sand grains. Eur J Phycol [Internet]. 2006 May [cited 2018 Aug 2];41(2):131-46. Available from: http://www.tandfonline.com/doi/abs/10.1080/09670260600652903 
224. Vilbaste $S$, Truu J. Distribution of benthic diatoms in relation to environmental variables in lowland streams. Hydrobiologia [Internet]. 2003 [cited 2018 Aug 2];493(1/3):81-93. Available from: http://link.springer.com/10.1023/A:1025401716441

225. O'Hare MT, Mountford JO, Maroto J, Gunn IDM. Plant Traits Relevant To Fluvial Geomorphology and Hydrological Interactions. River Res Appl [Internet]. 2016 Feb 1 [cited 2018 Aug 1];32(2):17989. Available from: http://doi.wiley.com/10.1002/rra.2940

226. Riis T, Sand-Jensen K. Dispersal of plant fragments in small streams. Freshw Biol [Internet]. 2006 Feb 1 [cited 2018 Aug 1];51(2):274-86. Available from: http://doi.wiley.com/10.1111/j.13652427.2005.01496.x

227. Riis T, Madsen T V., Sennels RSH. Regeneration, colonisation and growth rates of allofragments in four common stream plants. Aquat Bot [Internet]. 2009 Feb 1 [cited 2018 Aug 1];90(2):209-12. Available from: https://www.sciencedirect.com/science/article/pii/S0304377008001423

228. Trimmer M, Sanders IA, Heppell CM. Carbon and nitrogen cycling in a vegetated lowland chalk river impacted by sediment. Hydrol Process [Internet]. 2009 Jul 15 [cited 2018 Aug 1];23(15):2225-38. Available from: http://doi.wiley.com/10.1002/hyp.7276

229. Francis R a., Gurnell AM. Initial establishment of vegetative fragments within the active zone of a braided gravel-bed river (River Tagliamento, NE Italy). Wetlands [Internet]. 2006 [cited 2018 Aug 1];26(3):641-8. Available from: https://link.springer.com/article/10.1672/02775212(2006)26[641:IEOVFW]2.0.CO;2

230. Moggridge HL, Gurnell AM. Controls on the sexual and asexual regeneration of Salicaceae along a highly dynamic, braided river system. Aquat Sci [Internet]. 2009 Oct 17 [cited 2018 Aug 1];71(3):305-17. Available from: http://link.springer.com/10.1007/s00027-009-9193-3

231. Francis RA, Gurnell AM, Petts GE, Edwards PJ. Survival and growth responses of Populus nigra, Salix elaeagnos and Alnus incana cuttings to varying levels of hydric stress. For Ecol Manage [Internet]. 2005 May 16 [cited 2018 Aug 1];210(1-3):291-301. Available from: https://www.sciencedirect.com/science/article/pii/S0378112705001283

232. Dawson FH. The seasonal effects of aquatic plant growth on the flow of water in a stream. 5th Int Symp Aquat Weeds Eur Weed Res Soc [Internet]. 1978 [cited 2018 Aug 2];71-8. Available from: http://agris.fao.org/agris-search/search.do?recordID=XE7980599

233. Kleeberg A, Köhler J, Sukhodolova T, Sukhodolov A. Effects of aquatic macrophytes on organic matter deposition, resuspension and phosphorus entrainment in a lowland river. Freshw Biol [Internet]. 2010 Feb 1 [cited 2018 Aug 2];55(2):326-45. Available from: http://doi.wiley.com/10.1111/j.1365-2427.2009.02277.x

234. Dawson $\mathrm{FH}$, Castellano $\mathrm{E}$, Ladle $\mathrm{M}$. The concept of species succession in relation to river vegetation and management. Verhandlungen Int Verein für Theor und Angew Limnol [Internet]. 1978 Oct [cited 2018 Aug 1];20(JANUARY 1978):1451-6. Available from: https://www.tandfonline.com/doi/full/10.1080/03680770.1977.11896707

235. Sand-Jensen K. Macrophytes as biological engineers in the ecology of Danish streams. Freshw Biol Priorities Dev Danish Res [Internet]. 1997 [cited 2018 Aug 2];74-101. Available from: http://www.forskningsdatabasen.dk/en/catalog/2398156347 
236. Grime JP. Plant Strategies, Vegetation Processes, and Ecosystem Properties. Second ed. New York: John Wiley \& Sons; 2001. 417 p.

237. Jones JI, Murphy JF, Anthony SG, Arnold A, Blackburn JH, Duerdoth CP, et al. Do agri-environment schemes result in improved water quality? McKenzie A, editor. J Appl Ecol [Internet]. 2017 Apr 1 [cited 2018 Aug 2];54(2):537-46. Available from: http://doi.wiley.com/10.1111/1365-2664.12780

238. Growns I, Murphy JF, Jones JI. The effects of altered flow and bed sediment on macroinvertebrates in stream mesocosms. Mar Freshw Res [Internet]. 2017 Mar 21 [cited 2018 Aug 6];68(3):496-505. Available from: http://www.publish.csiro.au/?paper=MF15160

239. Carl Richards KLB. Influence of fine sediment on macroinvertebrate colonization of surface and hyporheic stream substrates. Gt Basin Nat [Internet]. 1994 [cited 2018 Aug 1];54(2):106-13. Available from: http://www.jstor.org/stable/41712819

240. Descloux S, Datry T, Marmonier P. Benthic and hyporheic invertebrate assemblages along a gradient of increasing streambed colmation by fine sediment. Aquat Sci [Internet]. 2013 Oct 30 [cited 2018 Aug 1];75(4):493-507. Available from: http://link.springer.com/10.1007/s00027-0130295-6

241. Larsen S, Vaughan IP, Ormerod SJ. Scale-dependent effects of fine sediments on temperate headwater invertebrates. Freshw Biol [Internet]. 2009 Jan 1 [cited 2018 Aug 2];54(1):203-19. Available from: http://doi.wiley.com/10.1111/j.1365-2427.2008.02093.x

242. Townsend CR, Hildrew AG. Species traits in relation to a habitat templet for river systems. Freshw Biol [Internet]. 1994 Jun 1 [cited 2018 Aug 1];31(3):265-75. Available from: http://doi.wiley.com/10.1111/j.1365-2427.1994.tb01740.x

243. Doretto A, Bona F, Piano E, Zanin I, Eandi AC, Fenoglio S. Trophic availability buffers the detrimental effects of clogging in an alpine stream. Sci Total Environ [Internet]. 2017 Aug 15 [cited 2018 Aug 1];592:503-11. Available from: https://www.sciencedirect.com/science/article/pii/S0048969717306228

244. Wilkes MA, Mckenzie M, Murphy JF, Chadd RP. Assessing the Mechanistic Basis for Fine Sediment Biomonitoring: Inconsistencies among the Literature, Traits and Indices. River Res Appl [Internet]. 2017 Dec 1 [cited 2018 Aug 1];33(10):1618-29. Available from: http://doi.wiley.com/10.1002/rra.3139

245. Couceiro SRM, Hamada N, Forsberg BR, Padovesi-Fonseca C. Effects of anthropogenic silt on aquatic macroinvertebrates and abiotic variables in streams in the Brazilian Amazon. J Soils Sediments [Internet]. 2009 Jan 10 [cited 2018 Aug 1];10(1):89-103. Available from: http://link.springer.com/10.1007/s11368-009-0148-z

246. Descloux S, Datry T, Usseglio-Polatera P. Trait-based structure of invertebrates along a gradient of sediment colmation: Benthos versus hyporheos responses. Sci Total Environ [Internet]. 2014 Jan 1 [cited $2018 \mathrm{Jul}$ 18];466-467:265-76. Available from: https://www.sciencedirect.com/science/article/pii/S0048969713007341

247. Bona F, Doretto A, Falasco E, La Morgia V, Piano E, Ajassa R, et al. Increased Sediment Loads in Alpine Streams: An Integrated Field Study. River Res Appl [Internet]. 2016 Jul [cited 2018 Jul 18];32(6):1316-26. Available from: http://doi.wiley.com/10.1002/rra.2941 
248. Relyea CD, Minshall GW, Danehy RJ. Stream Insects As Bioindicators of Fine Sediment. Proc Water Environ Fed [Internet]. 2000 Jan 1 [cited 2018 Aug 1];2000(6):663-86. Available from: http://www.ingentaconnect.com/content/10.2175/193864700785150123

249. Rabení CF, Doisy KE, Zweig LD. Stream invertebrate community functional responses to deposited sediment. Aquat Sci [Internet]. 2005 Dec 11 [cited 2018 Aug 1];67(4):395-402. Available from: http://link.springer.com/10.1007/s00027-005-0793-2

250. Mathers KL, Hill MJ, Wood PJ. Benthic and hyporheic macroinvertebrate distribution within the heads and tails of riffles during baseflow conditions. Hydrobiologia [Internet]. 2017 Jun 19 [cited 2018 Aug 1];794(1):17-30. Available from: http://link.springer.com/10.1007/s10750-017-3092-8

251. Bo T, Fenoglio S, Malacarne G, Pessino M, Sgariboldi F. Effects of clogging on stream macroinvertebrates: An experimental approach. Limnologica [Internet]. 2007 May 30 [cited 2018 Aug 1];37(2):186-92. Available from: https://www.sciencedirect.com/science/article/pii/S0075951107000060

252. Datry T, Lamouroux N, Thivin G, Descloux S, Baudoin JM. Estimation of Sediment Hydraulic Conductivity in River Reaches and its Potential Use to Evaluate Streambed Clogging. River Res Appl [Internet]. 2015 Sep 1 [cited 2018 Aug 1];31(7):880-91. Available from: http://doi.wiley.com/10.1002/rra.2784

253. Gayraud S, Philippe M. Does subsurface interstitial space influence general features and morphological traits of the benthic macroinvertebrate community in streams? Arch Fur Hydrobiol [Internet]. 2001 Jul 9 [cited 2018 Aug 1];151(4):667-86. Available from:

http://www.schweizerbart.de/papers/fal/detail/151/85869/Does_subsurface_interstitial_space_ influence_gener?af=crossref

254. Mathers KL, Rice SP, Wood PJ. Temporal effects of enhanced fine sediment loading on macroinvertebrate community structure and functional traits. Sci Total Environ [Internet]. 2017 Dec 1 [cited 2018 Aug 1];599-600:513-22. Available from: https://www.sciencedirect.com/science/article/pii/S0048969717309312

255. Braccia A, Voshell JR. Environmental factors accounting for benthic macroinvertebrate assemblage structure at the sample scale in streams subjected to a gradient of cattle grazing. Hydrobiologia [Internet]. 2006 Dec 2 [cited 2018 Aug 1];573(1):55-73. Available from: http://link.springer.com/10.1007/s10750-006-0257-2

256. Cover MR, May CL, Dietrich WE, Resh VH. Quantitative linkages among sediment supply, streambed fine sediment, and benthic macroinvertebrates in northern California streams. J North Am Benthol Soc [Internet]. 2008 Mar 19 [cited 2018 Jul 19];27(1):135-49. Available from: http://www.journals.uchicago.edu/doi/10.1899/07-032.1

257. Buendia C, Gibbins CN, Vericat D, Batalla RJ, Douglas A. Detecting the structural and functional impacts of fine sediment on stream invertebrates. Ecol Indic [Internet]. 2013 Feb 1 [cited 2018 Jul 19];25:184-96. Available from:

https://www.sciencedirect.com/science/article/pii/S1470160X12003512

258. Lemly AD. Modification of benthic insect communities in polluted streams: combined effects of sedimentation and nutrient enrichment. Hydrobiologia [Internet]. 1982 Mar [cited 2018 Aug 
2];87(3):229-45. Available from: http://link.springer.com/10.1007/BF00007232

259. Townsend CR, Uhlmann SS, Matthaei CD. Individual and combined responses of stream ecosystems to multiple stressors. J Appl Ecol [Internet]. 2008 Dec 1 [cited 2018 Aug 2];45(6):1810-9. Available from: http://doi.wiley.com/10.1111/j.1365-2664.2008.01548.x

260. Everall NC, Johnson MF, Wood P, Mattingley L. Sensitivity of the early life stages of a mayfly to fine sediment and orthophosphate levels. Environ Pollut [Internet]. 2018 Jun 1 [cited 2018 Aug 2];237:792-802. Available from: https://www.sciencedirect.com/science/article/pii/S0269749117329792

261. Dolédec S, Phillips N, Scarsbrook MR, Riley RH, Townsend CR, Dolédec S, et al. Comparison of structural and functional approaches to determining landuse effects on grassland stream invertebrate communities. J North Am Benthol Soc [Internet]. 2006;25(1):44-60. Available from: isi:000236565400005

262. Lange K, Townsend CR, Matthaei CD. Can biological traits of stream invertebrates help disentangle the effects of multiple stressors in an agricultural catchment? Freshw Biol [Internet]. 2014 Dec 1 [cited 2018 Aug 1];59(12):2431-46. Available from: http://doi.wiley.com/10.1111/fwb.12437

263. Larsen S, Pace G, Ormerod SJ. Experimental effects of sediment deposition on the structure and function of macroinvertebrate assemblages in temperate streams. River Res Appl [Internet]. 2011 Feb 1 [cited 2018 Aug 2];27(2):257-67. Available from: http://doi.wiley.com/10.1002/rra.1361

264. Verberk WCEP, van Noordwijk CGE, Hildrew AG. Delivering on a promise: integrating species traits to transform descriptive community ecology into a predictive science. Freshw Sci [Internet]. 2013 Jun 17 [cited 2018 Aug 1];32(2):531-47. Available from: http://www.journals.uchicago.edu/doi/10.1899/12-092.1

265. Redding J, Schreck C. Mount St. Helens ash causes sublethal stress response in steelhead trout. In Washington Water Research Centre proceeding from the Conference, Mt. St. Helens-effects on water resources: Report 41. Washington Water Research Center: Pullman, WA; 1982.

266. Bond NR, Downes BJ. The independent and interactive effects of fine sediment and flow on benthic invertebrate communities characteristic of small upland streams. Freshw Biol [Internet]. 2003 Mar [cited 2018 Jul 18];48(3):455-65. Available from: http://doi.wiley.com/10.1046/j.13652427.2003.01016.x

267. Sutherland $A B$, Meyer JL. Effects of increased suspended sediment on growth rate and gill condition of two southern Appalachian minnows. Environ Biol Fishes [Internet]. 2007 Oct 22 [cited 2018 Aug 2];80(4):389-403. Available from: http://link.springer.com/10.1007/s10641-0069139-8

268. McCubbin R, Case A, Rowe D, Scruton D. Environmental effects of sediments on aquatic habitats and suggested mitigation. Appendix IV. In: Resource Road Construction: Fish Habitat Protection Guidelines. S.t John's, New Foundland: Canadian Forest Service and Department of Fisheries and Oceans; 1990. p. 65.

269. Ahlbert I. The organisation of the cone cells in the retinae of four teleosts with different feeding 
habits (Perca fluviatilis L., Lucioperca lucioperca L., Acerina cernua L. and <i>Coregonus albula L). Ark Zool [Internet]. 1969 [cited 2018 Aug 2];22(11):445-81. Available from: https://ci.nii.ac.jp/naid/10020860423/

270. Ali MA, Ryder RA, Anctil M. Photoreceptors and Visual Pigments as Related to Behavioral Responses and Preferred Habitats of Perches (Perca spp.) and Pikeperches (Stizostedion spp.). J Fish Res Board Canada [Internet]. 1977 Oct [cited 2018 Aug 2];34(10):1475-80. Available from: http://www.nrcresearchpress.com/doi/abs/10.1139/f77-212

271. Bergman E. Foraging Abilities and Niche Breadths of Two Percids, Perca Fluviatilis and Gymnocephalus Cernua, Under Different Environmental Conditions. J Anim Ecol [Internet]. 1988 Jun [cited 2018 Aug 2];57J(57):443-53. Available from: http://www.jstor.org/stable/4916\%0Ahttp://www.jstor.org/page/info/about/policies/terms.jsp \%0Ahttp://www.jstor.org

272. Franklin PA, Smith J, Baker CF, Bartels B, Reeve K. First observations on the timing and location of giant kokopu (Galaxias argenteus) spawning. New Zeal J Mar Freshw Res [Internet]. 2015 Jul 3 [cited 2018 Aug 2];49(3):419-26. Available from: http://www.tandfonline.com/doi/full/10.1080/00288330.2015.1045004

273. Power ME. The importance of sediment in the grazing ecology and size class interactions of an armored catfish, Ancistrus spinosus. Environ Biol Fishes [Internet]. 1984 Apr [cited 2018 Aug 2];10(3):173-81. Available from: http://link.springer.com/10.1007/BF00001124

274. Doan KH. Relation of Sauger Catch to Turbidity in Lake Erie. Ohio J Sci [Internet]. 1941 [cited 2018 Aug 2];41(6):449-52. Available from: https://kb.osu.edu/dspace/bitstream/handle/1811/3200/1/V41N06_449.pdf

275. Kulíšková P, Horký P, Slavík O, Jones Jl. Factors influencing movement behaviour and home range size in ide Leuciscus idus. J Fish Biol [Internet]. 2009 Apr 1 [cited 2018 Aug 2];74(6):1269-79. Available from: http://doi.wiley.com/10.1111/j.1095-8649.2009.02198.x

276. Zamor RM, Grossman GD. Turbidity Affects Foraging Success of Drift-Feeding Rosyside Dace. Trans Am Fish Soc [Internet]. 2007 Jan 9 [cited 2018 Aug 2];136(1):167-76. Available from: http://www.tandfonline.com/doi/abs/10.1577/T05-316.1

277. Fairchild JF, Boyle T, English WR, Rabeni C. Effects of sediment and contaminated sediment on structural and functional components of experimental stream ecosystems. Water Air Soil Pollut [Internet]. 1987 [cited 2018 Aug 2];36(3-4):271-93. Available from: http://link.springer.com/10.1007/BF00229673

\section{Further Reading}

None. The bibliography is extensive. 


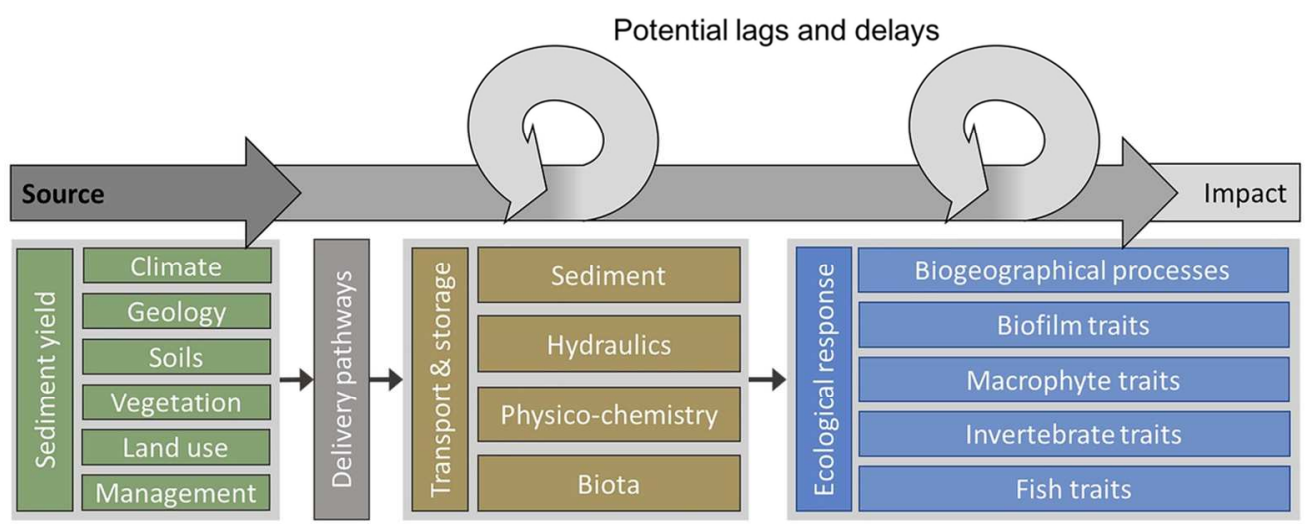

$114 \times 46 \mathrm{~mm}(300 \times 300 \mathrm{DPI})$ 
Figure 1 - Controls on the delivery, transport and storage of fine sediment and the resulting ecological responses in river networks. Natural and anthropogenic factors control the quantity and quality of sediment potentially available for delivery to the river channel. Whether or not this potential is realised, and the quantity and composition of sediment conserved during the pluvial phase, depends on delivery pathways that connect the source to the river channel. Once delivered to the river channel, particles may be transported through suspension or saltation, temporarily stored as surface-deposited material, or become infiltrated in the river bed and stored on a longer-term basis. Which compartment particles are transported or stored in depends on a number of controls, including the inherent properties of the particles, hydraulics, and the activities of biota. The latter is in turn influenced by physico-chemical factors (e.g. oxygen, nutrients) that work to limit or enhance biological processes. The hydraulic and biological controls determine the compartments within which particles are transported or stored, structuring the physical habitat, modifying available resources and potentially filtering out unsuitable species from the species pool on the basis of their traits. Such environmental filtering effects may be interfered with by biogeographical processes related to dispersal. The fate of fine sediment, and the extent and nature of the impact it causes is subject to potential lags as sediment is temporarily stored within the landscape. Ecological impacts may also be delayed as time is taken for local populations to reach critical life-stages where fine sediment limits survival.

$188 \times 124 \mathrm{~mm}(300 \times 300 \mathrm{DPI})$ 


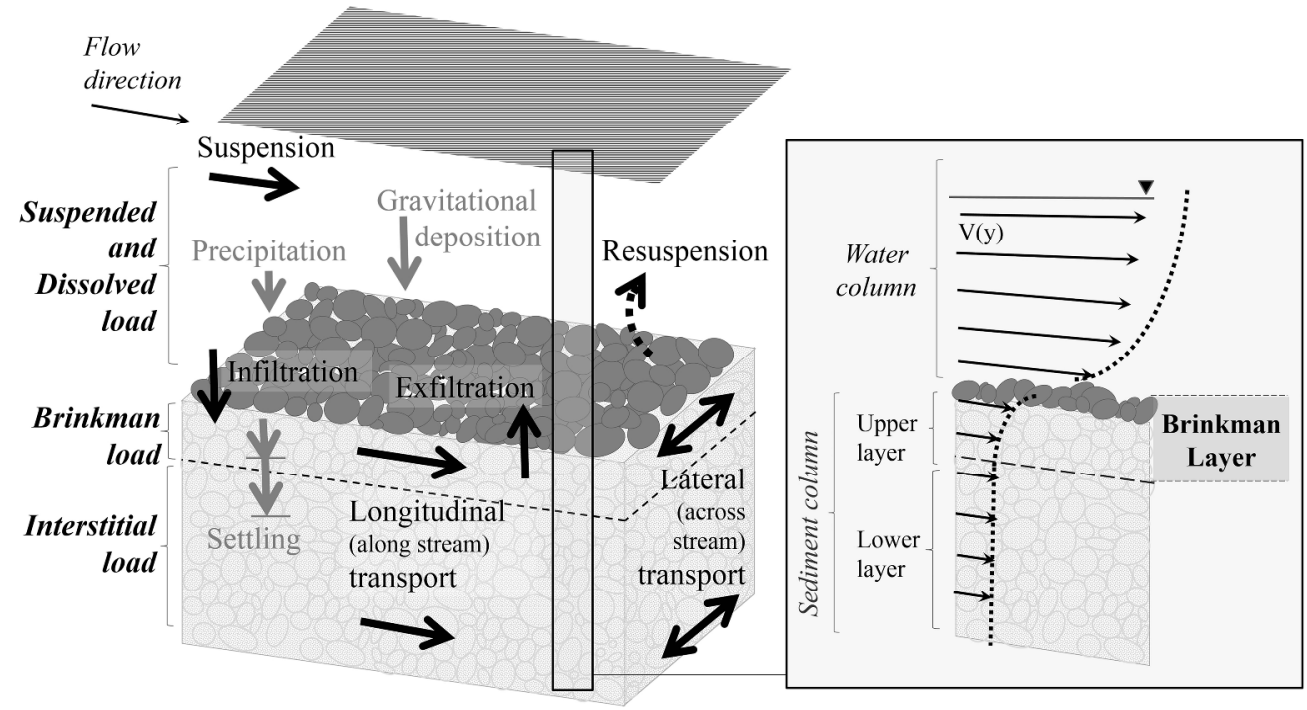

Figure 2 - Fine sediment transport (black arrows) and deposition (grey arrows) processes in gravel beds. These processes occur in three key load regions (suspended and dissolved load, Brinkman load and interstitial load) within the water and sediment columns in which such processes occur (left). The model proposes distinct modes of sediment transport in these three regions identified by transitions in the velocity profile $V(y)$ (right). Modified from ${ }^{43}$. 


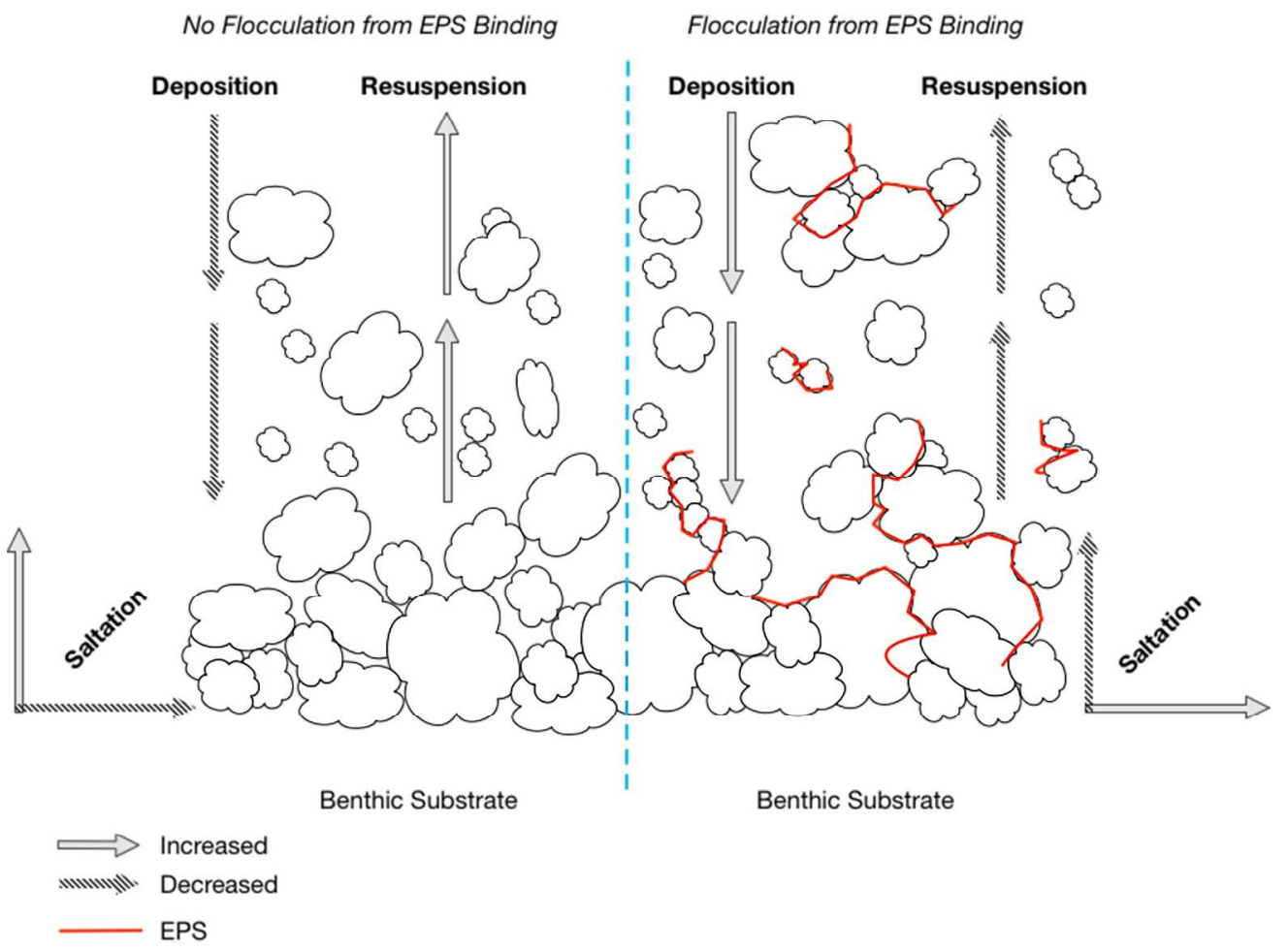

Figure 3 - Controls on fine sediment deposition and resuspension exerted through bioflocculation by extracellular polymeric substances (EPS) in biofilms.

$218 \times 164 \mathrm{~mm}(300 \times 300 \mathrm{DPI})$

John Wiley \& Sons 
(a) Dominant community assembly processes

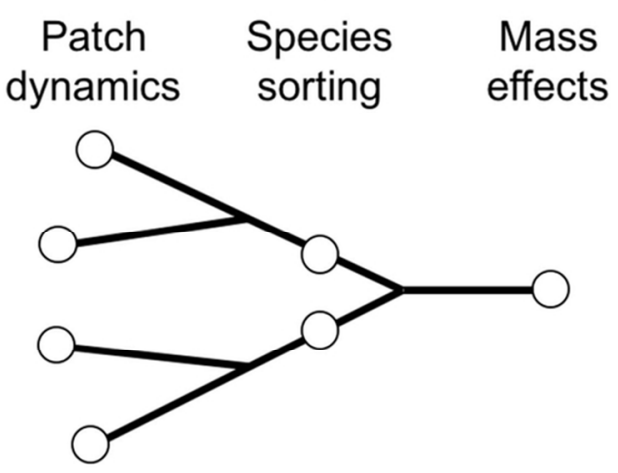

(b)

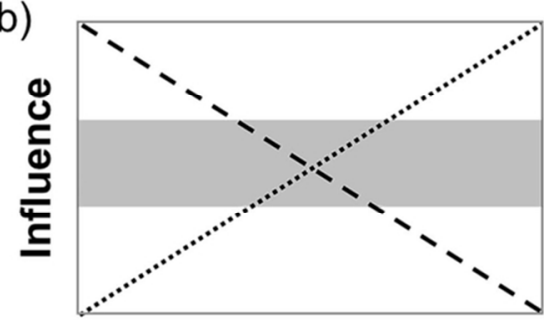

Stream order

- - Demographic stochasticity

..... Dispersal (mass effects) Species sorting

Figure 4 - Metacommunity theory predicts patterns in dominant community assembly processes in river networks (a) due to variation in spatial, environmental and demographic influences with stream order (b), with implications for ecosystem responses to stressors. Headwater communities are likely to follow the patch

dynamics paradigm, whereby local species diversity is limited by dispersal and community structure becomes a function of stochastic demographic processes involving local extinction and colonisation 195 . The structure of lower mainstem communities is predicted to more closely resemble the regional species pool since high dispersal rates drown out the influence of local environment through 'mass effects'195. In midbasin locations, species sorting or 'environmental filtering'194 is made possible as the influence of dispersal is at an optimal level to allow for efficient niche-based processes 199.

$91 \times 41 \mathrm{~mm}(300 \times 300$ DPI $)$ 